\title{
Vertebrate microfossils from the Upper Freshwater Molasse in the Swiss Molasse Basin: Implications for the evolution of the North Alpine Foreland Basin during the Miocene Climate Optimum
}

\begin{abstract}
Authors: Jürg Jost, Daniel Kälin, Saskia Börner, Davit Vasilyan, Daniel Lawver, \& Bettina Reichenbacher

NOTICE: this is the author's version of a work that was accepted for publication in Palaeogeography, Palaeoclimatology, Palaeoecology. Changes resulting from the publishing process, such as peer review, editing, corrections, structural formatting, and other quality control mechanisms may not be reflected in this document. Changes may have been made to this work since it was submitted for publication. A definitive version was subsequently published in Palaeogeography, Palaeoclimatology, Palaeoecology, [Vol\# 426, (May 15, 2015)] DOI\# 10.1016/j.palaeo.2015.02.028
\end{abstract}

Jost, Jurg, Daniel Kalin, Saskia Borner, Davit Vasilyan, Daniel Lawver, and Bettina Reichenbacher. "Vertebrate microfossils from the Upper Freshwater Molasse in the Swiss Molasse Basin: Implications for the evolution of the North Alpine Foreland Basin during the Miocene Climate Optimum." Palaeogeography, Palaeoclimatology, Palaeoecology 426 (May 2015): 22-33. DOI: https://dx.doi.org/10.1016/j.palaeo.2015.02.028 


\title{
Vertebrate microfossils from the Upper Freshwater Molasse in the Swiss Molasse Basin: Implications for the evolution of the North Alpine Foreland Basin during the Miocene Climate Optimum
}

\author{
Jürg Jost ${ }^{a}$, Daniel Kälin ${ }^{b}$, Saskia Börner ${ }^{c}$, Davit Vasilyan ${ }^{d}$, Daniel Lawver ${ }^{\mathrm{e}}$, Bettina Reichenbacher ${ }^{\mathrm{c}}$ \\ a Bärenhubelstraße 10, CH-4800 Zofingen, Switzerland \\ b Bundesamt für Landestopographie swisstopo, Geologische Landesaufnahme, Seftigenstrasse 264, 3084 Wabern, Switzerland \\ c Department of Earth and Environmental Sciences, Section on Palaeontology and Geobiology, Ludwig-Maximilians-University, Richard-Wagner Str. 10, D-80333 \\ Munich, Germany \\ d Department of Geosciences, Eberhard-Karls University Tübingen, Sigwartstr. 10, D-72076 Tübingen, Germany \\ e Department of Earth Sciences, Montana State University, Bozeman, MT 59718, USA
}

\begin{abstract}
The older part of the Upper Freshwater Molasse (OSM) in the Swiss and South German Molasse Basin records the extended warm period known as the Miocene Climate Optimum. However, dating and global correlation of fossils and palaeoclimatic data from OSM sediments remains challenging, because sections are often incomplete and biostratigraphic data sometimes ambiguous. Here we present the rare case of a fossiliferous OSM section that can be securely dated to the late Early Miocene and early Middle Miocene (c. 16.1-15.7 Ma). Vertebrate microfossils have been recovered from three levels in superposition. Fish teeth document primary freshwater fishes (Cyprinidae, Channidae), but otoliths found in the middle level indicate dominance of euryhaline fishes (Cyprinodontiformes, Gobiiformes). The herpetofaunal assemblages largely consist of taxa that were widely dis-tributed in Central Europe during the Miocene Climate Optimum and fragments of turtle eggshells assignable to the Oofamily Testudoolithidae Hirsch, 1996. The small-mammal fauna is dominated by the cricetid Megacricetodon bavaricus Fahlbusch, 1964. The fossil biota implies that the lowermost level (late Early Miocene, c. 16.1 Ma) represents a palaeo-soil that formed under humid conditions, while the levels above it (early Middle Miocene, c.15.7-15.8 Ma) record a warm freshwater pond subject to evaporation (middle level), and mean an-nual temperature $\geq 17^{\circ} \mathrm{C}$ in the vicinity of a river with an open hinterland (upper level). Our results, together with previous data, suggest that the palaeoclimate of the North Alpine Foreland Basin of Switzerland and South-west Germany was humid during the late Early Miocene and earliest Middle Miocene, and that the Middle Mio-cene onset of seasonality and low mean annual precipitation occurred by c. 15.7-15.8 Ma. We conclude that global climate change and the 100-kyr orbital eccentricity minimum at 15.75 Ma may have triggered the decrease in humidity in the North Alpine Foreland Basin.
\end{abstract}

\section{Introduction}

Marine, brackish, freshwater and terrestrial deposits characterize the sedimentary record of the Swiss and South German Molasse Basin in the North Alpine Foreland Basin during the Miocene Climate Optimum (late Early Miocene-early Middle Miocene). However, the chronostratigraphic age of the Molasse sediments is often unclear, and interpretation of palaeoenvironmental evidence derived from fossils in the context of regional and global climate change remains difficult. This is particularly true for the continental deposits of the largely Middle Miocene Upper Freshwater Molasse (OSM), because biostratigraphically informative fossils or ash layers that can be dated radiometrically are rare in these sediments.
Several fossiliferous sites have been discovered in the OSM of the Swiss and South German Molasse Basin during the last decade, and a variety of studies on various groups of fossils have addressed late Early Miocene to Middle Miocene biostratigraphy, palaeoenvironment and palaeoclimate. Examples include work on amphibians and reptiles (Böhme, 2003, 2010; Böhme et al., 2006; Böhme et al., 2011), fish otoliths and teeth (Reichenbacher, 1999; Reichenbacher et al., 2004; Reichenbacher and Prieto, 2006; Sach et al., 2003), small-mammal teeth (Abdul Aziz et al., 2010; Abdul Aziz et al., 2008; Kälin and Kempf, 2009; Prieto et al., 2009), large-mammal remains (Eronen and Rössner, 2007), pollen (Jiménez-Moreno et al., 2008) and wood flora (Böhme et al., 2007). Rasser et al. (2013) have analysed the palaeoenvironment and palaeoclimate of the fossil Lagerstätte Randecker Maar, which is contemporaneous with the older part of 
the OSM, and isotope data have also been used for palaeoclimate reconstructions (Reichenbacher et al., 2004; Tütken et al., 2006). All these studies produced evidence for a warm-temperate to subtropical climate with periods of seasonality and aridity, but correlation between regional climate trends and global climate change is complicated by truncation of sections and ambiguities in the biostratigraphic data (see Reichenbacher et al., 2013).

This study is based on the Schmiedrued-Pfyffrüti (SP) section in the Molasse Basin of Central Switzerland (Fig. 1), where sediments of the OSM datable to the late Early Miocene and early Middle Miocene (c. 16.1-15.7 Ma) are exposed (see below). The objective of our study is to describe fossil biota from three different levels in superposition (Fig. 2) and review their implications for palaeoenvironment and palaeoclimate in the North Alpine Foreland Basin during the interval considered. The study focuses on the vertebrate material (otoliths and teeth of fish, bones and teeth of reptiles and amphibians, fragments of a turtle eggshell, and small-mammal teeth), but charophytes and molluscs are also considered.

\section{Geological setting}

The Swiss and South German Molasse Basin is part of the North Alpine Foreland Basin extending from Lake Geneva in the West to the Vienna Basin in the East. The oldest Molasse sediments date from the Early Oligocene, while the youngest deposits are Late Miocene in age (e.g. Doppler et al., 2005). Erosional debris from the uplifting Alps was the main source for the sediments in the Molasse Basin, with lesser amounts of material being derived from sources to the North; directions of sediment transport were axial and radial (e.g. Kuhlemann and Kempf, 2002; Lemcke, 1988). Four main lithostratigraphic groups have been established, comprising (from bottom to top) the Lower Marine Molasse, the Lower Freshwater Molasse, the Upper Marine Molasse, and the Upper Freshwater Molasse (Doppler et al., 2005; Lemcke, 1988).

Deposition of the continental Upper Freshwater Molasse (OSM) had begun by the late Early Miocene and continued until the Late Miocene (Doppler et al., 2005; Heissig, 1997; Lemcke, 1988). The most widespread OSM sediments in the Molasse Basin are of fluvial origin and derive from a large, NE-SW flowing river system (Glimmersandfluss). These sediments can reach a few hundreds of metres in thickness, and usually consist of pebbles, sands and silts (Berger et al., 2005; Lemcke, 1988). In addition, thick conglomerates occur along the proximal and distal margins of the Molasse Basin, and represent alluvial fans from the Alps and the northern mainland, respectively (e.g. Berger et al.,
2005; Lemcke, 1988; Scholz, 1989). Lacustrine sediments may reach a few decimetres to metres in thickness and consist of marls, silts, clays and limestones that were deposited in perennial lakes or ephemeral ponds (Böhme, 2010; Böttcher et al., 2009; Rasser et al., 2013; Reichenbacher et al., 2004; Reichenbacher and Prieto, 2006); overall, this type of sediment is rare among OSM deposits. Terrestrial sediments are mainly represented by soils that are occasionally intercalated in the fluvial successions (Böhme, 2003; Prieto et al., 2009).

\section{Materials and methods}

\subsection{Study site}

The Schmiedrued-Pfyffrüti (SP) outcrop studied here is located in the Swiss Molasse Basin, within the distal part of the Napf fan in Central Switzerland $\left(47^{\circ} 16.495^{\prime} \mathrm{N}, 8^{\circ} 7.021^{\prime} \mathrm{E}\right)$ (Fig. 1). It is about $100 \mathrm{~m}$ thick and comprises $\sim 57 \mathrm{~m}$ of Upper Marine Molasse and $\sim 43 \mathrm{~m}$ of Upper Freshwater Molasse (OSM). The lower part of the OSM has been investigated using bio-, litho- and magnetostratigraphy; a normal polarity interval corresponding to chron $5 \mathrm{Cn} 1 \mathrm{n}$ (late Early Miocene) was recorded for the OSM base, while a reversed interval followed above it and was correlated to chron $5 \mathrm{Br}$ (early Middle Miocene) (Reichenbacher et al., 2013; see here Fig. 2).

The OSM sediments of SP consist of fine to medium-grained sandstones and grey to greenish mottled silts and clays with pedogenetic overprint (Graf et al., 2012) (Fig. 2). Intercalated, dark-coloured, fossiliferous levels with macroscopically visible gastropod shells (Fig. 3) occur at $618 \mathrm{~m}, 640 \mathrm{~m}$, and $642 \mathrm{~m}$. These levels yielded the fossil biota studied here. Based on bio- and magnetostratigraphic data, SP 618 is c. 16.1-16.2 m.y. old (late Early Miocene), while SP 640 and 642 are c. 15.7-15.8 m.y. old (early Middle Miocene); SP 640 corresponds to the small-mammal unit (lower) MN 5 and to the otolith zone OT-M5b (Reichenbacher et al., 2013).

\subsection{Materials and methods}

A total of $950 \mathrm{~kg}$ of sediment was collected from the fossiliferous levels (SP 618, 500 kg; SP 640, 250 kg; SP 642, 200 kg). Samples were processed by soaking in hydrogen peroxide solution for several hours, and washed through $300 \mu \mathrm{m}$ and $400 \mu \mathrm{m}$ mesh sieves. The remaining material was dried in air and all microfossils down to a grain size of $400 \mu \mathrm{m}$ were picked; material of smaller sizes was picked from representative splits of the samples.

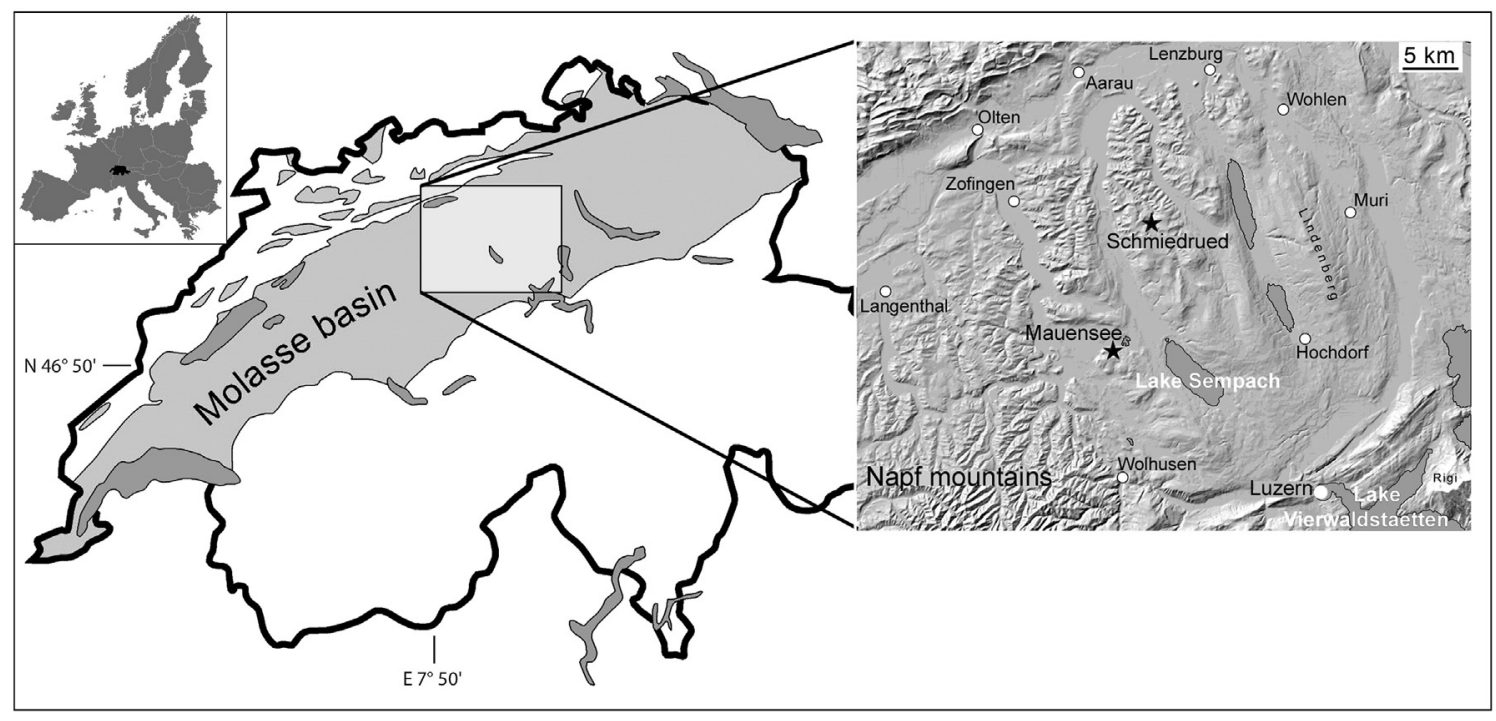

Fig. 1. Location of the Schmiedrued-Pfyffrüti section in the Molasse Basin of Switzerland. Inset shows location of Switzerland (dark coloured) in Central Europe. 


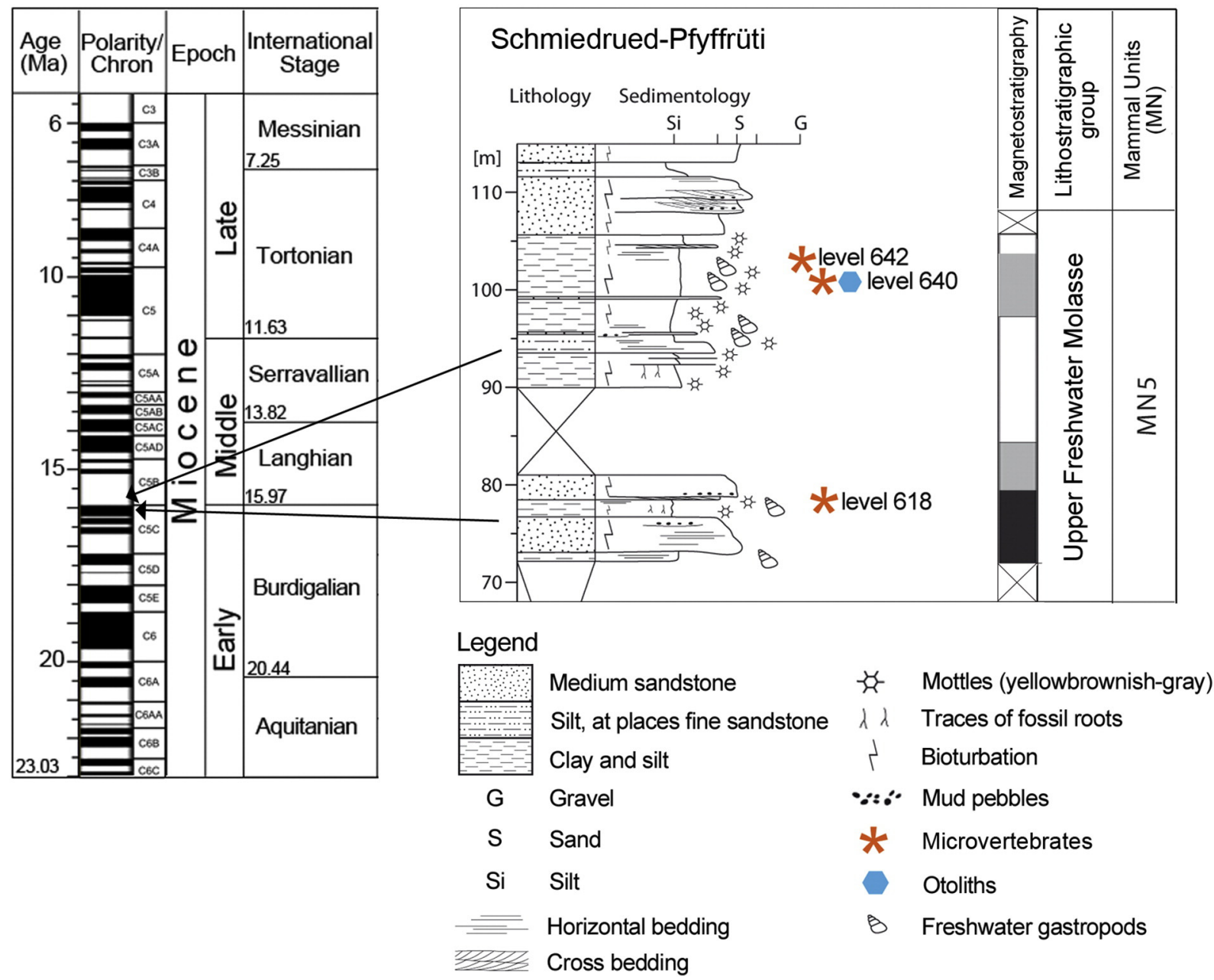

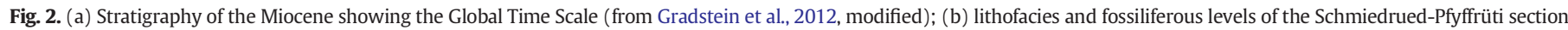
(from Graf et al., 2012, modified) and magnetostratigraphic pattern and chronostratigraphic position according to Reichenbacher et al. (2013).

Identification of fossil taxa was based on morphological characters and morphometric analysis of specimens examined by stereo- or scanning-electron microscopy. Photographs of the fossil bones and otoliths were taken with Leica DVM 5000 and M165C digital microscopes, respectively. SEM pictures and thin sections of two eggshell samples were prepared by Ralf Kohring (FU Berlin). The actualistic method, which assumes that the ecological demands of any given fossil

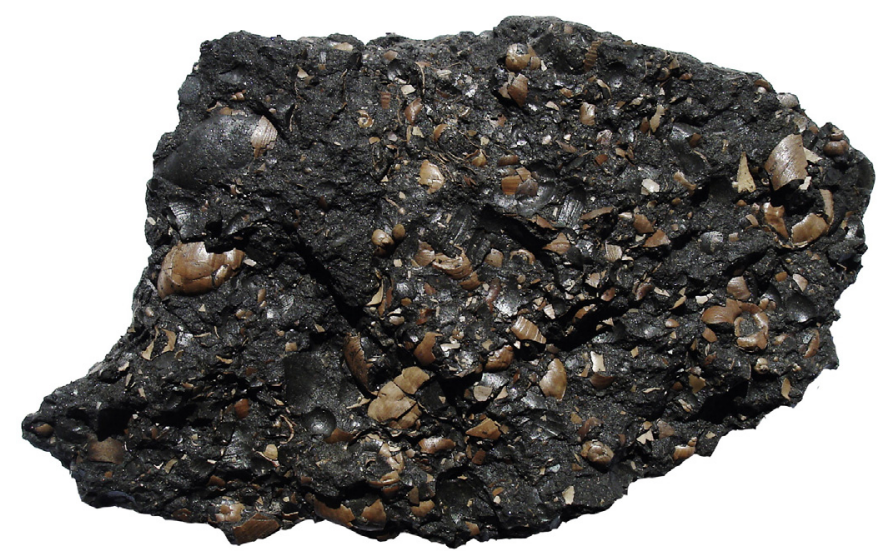

Fig. 3. Sample from level 640 showing its typical dark colour and shells of numerous gastropods. species were similar to those of its nearest living relative, was employed for palaeoecological reconstructions (e.g. Etter, 1994). This approach is especially well suited for the analysis of Miocene and younger palaeoecosystems, because the ecological requirements of Miocene or younger taxa are indeed likely to have been very similar to those of their nearest extant relatives.

The otoliths, fish teeth and reptile remains figured here are kept in the Bavarian State Collection for Palaeontology and Geology (SNSBBSPG 2015 IV) and figured mammal teeth are deposited in the Natural History Museum Basel (NHM Sdr. 1-3). All other material is part of the private collection of J. Jost (Zofingen).

\section{Results}

\subsection{Charophytes, invertebrates}

Charophytes are largely absent in SP 618, but occur abundantly in SP 640 and 642 (Table 1).

The gastropod fauna could be identified only at genus level because most specimens were fragmented. Both freshwater gastropods (Bithynia, Ferrissia, Stagnicola, Gyraulus, Planorbarius) and terrestrial taxa are present (Vallonia, Limax, Helicacea indet., Oxychilidae indet.). Freshwater gastropods are rare in SP 618, whereas they are abundant in SP 640 and 642 (Table 1). Terrestrial gastropods are more abundant in SP 618 and SP 640 than in SP 642. Unionidae are the sole representatives of bivalves and are restricted to SP 642 . 
Table 1

Distribution of fossils in the studied levels Schmiedrued-Pfyffrüti 618, 640 and 642. Ecological requirements are also indicated (see text for details and references); $\mathrm{x}=$ present; $\mathrm{xx}=$ abundant (more than 20 specimens).

\begin{tabular}{|c|c|c|c|c|}
\hline \multicolumn{2}{|c|}{ Schmiedrued-Pfyffrüti } & \multirow[t]{2}{*}{618} & \multirow{2}{*}{$\begin{array}{l}640 \\
\mathrm{xx}\end{array}$} & \multirow{2}{*}{$\begin{array}{l}642 \\
\mathrm{xx}\end{array}$} \\
\hline $\begin{array}{l}\text { Charophyta } \\
\text { [All freshwater] }\end{array}$ & $\begin{array}{l}\text { Nitellopsis (Tectochara) ginsburgi Riveline, } \\
1985\end{array}$ & & & \\
\hline & Stephanochara rhabdocharoides Berger, 1983 & & $\mathrm{x}$ & \\
\hline & Charophyta indet & $\mathrm{x}$ & & \\
\hline Plants & Seeds and other remains & $\mathrm{x}$ & & $\mathrm{xx}$ \\
\hline \multirow[t]{9}{*}{ Gastropoda } & Bithynia sp. [freshwater] & $\mathrm{x}$ & $\mathrm{xx}$ & $\mathrm{xx}$ \\
\hline & Ferrissia sp. [freshwater] & & $\mathrm{x}$ & \\
\hline & Stagnicola sp. [freshwater] & & $\mathrm{x}$ & $\mathrm{xx}$ \\
\hline & Planorbarius sp. [freshwater] & & $\mathrm{x}$ & $\mathrm{xx}$ \\
\hline & Gyraulus sp. [freshwater] & $\mathrm{x}$ & $\mathrm{x}$ & $\mathrm{xx}$ \\
\hline & Vallonia sp. [terrestrial] & & $\mathrm{x}$ & \\
\hline & Limax sp. [terrestrial] & $\mathrm{x}$ & & $\mathrm{x}$ \\
\hline & Helicacea indet. [terrestrial] & $\mathrm{x}$ & & \\
\hline & Oxychilidae [terrestrial] & & $\mathrm{x}$ & \\
\hline Bivalvia & Unionidae [freshwater to oligohaline] & & & $\mathrm{x}$ \\
\hline \multirow[t]{2}{*}{ Fish teeth } & Palaeocarassius sp. [freshwater] & & $\mathrm{xx}$ & $\mathrm{xx}$ \\
\hline & Leuciscinae indet. [freshwater] & & $\mathrm{x}$ & $\mathrm{x}$ \\
\hline \multirow[t]{10}{*}{ Fish otoliths } & $\begin{array}{l}\text { Aphanolebias konradi (Reichenbacher, } \\
\text { 1988) [euryhaline] }\end{array}$ & & $>200$ & \\
\hline & “Gobius” brevis (Agassiz, 1839) [euryhaline] & & 93 & \\
\hline & $\begin{array}{l}\text { "Gobius" aff. brevis (Agassiz, 1839) } \\
\text { [euryhaline] }\end{array}$ & & 10 & \\
\hline & $\begin{array}{l}\text { Gobius gregori Reichenbacher, } 1993 \\
\text { [euryhaline] }\end{array}$ & & 48 & \\
\hline & Gobius helvetiae von Salis, 1967 [euryhaline] & & 73 & \\
\hline & Gobius longus von Salis, 1967 [freshwater] & & 7 & \\
\hline & Gobius sp. (morphotypes) & & $>200$ & \\
\hline & Channa elliptica von Salis, 1967 [freshwater] & & 18 & \\
\hline & Channa sp. (fragments) [freshwater] & & & 1 \\
\hline & Cyprinidae gen. et sp. indet [freshwater] & & $>200$ & \\
\hline Amphibia & Proteidae indet. [freshwater] & $\mathrm{x}$ & $\mathrm{x}$ & \\
\hline \multirow[t]{9}{*}{ Reptilia } & Gekkonidae indet. [terrestrial, heliophil] & & & $\mathrm{x}$ \\
\hline & Anguis sp. [terrestrial, fossorial] & $\mathrm{x}$ & & \\
\hline & Ophisaurus sp. [terrestrial, heliophil] & $\mathrm{x}$ & & \\
\hline & Anguidae indet. [terrestrial] & & $\mathrm{x}$ & $\mathrm{x}$ \\
\hline & Bavaricordylus sp. [terrestrial, heliophil] & & & $\mathrm{x}$ \\
\hline & Lacertidae indet. [terrestrial, heliophil] & $\mathrm{x}$ & & $\mathrm{x}$ \\
\hline & Amphisbenidae indet. [terrestrial, fossorial] & $\mathrm{x}$ & & \\
\hline & Crocodylia indet. [aquatic] & & $\mathrm{x}$ & $\mathrm{x}$ \\
\hline & Serpentes indet. [terrestrial] & & & $\mathrm{x}$ \\
\hline Turtle & Testudoolithidae [terrestrial] & $\mathrm{x}$ & $\mathrm{x}$ & $\mathrm{x}$ \\
\hline \multirow{8}{*}{$\begin{array}{l}\text { Mammalia } \\
\text { [All terrestrial] }\end{array}$} & Lipotyphla indet. & $\mathrm{x}$ & $\mathrm{x}$ & $\mathrm{x}$ \\
\hline & Soricidae indet. & & & $\mathrm{x}$ \\
\hline & Galerix sp. & $\mathrm{x}$ & $\mathrm{x}$ & $\mathrm{x}$ \\
\hline & Megacricetodon bavaricus Fahlbusch, 1964 & $\mathrm{xx}$ & $\mathrm{x}$ & $\mathrm{x}$ \\
\hline & Democricetodon gracilis Fahlbusch, 1964 & & & $\mathrm{x}$ \\
\hline & Miodyromys aff. aegercii Baudelot, 1972 & $\mathrm{x}$ & $\mathrm{x}$ & $\mathrm{x}$ \\
\hline & Microdyromys sp. & & & $\mathrm{x}$ \\
\hline & Prolagus oeningensis (König, 1825) & $\mathrm{x}$ & $\mathrm{x}$ & $\mathrm{x}$ \\
\hline
\end{tabular}

\subsection{Fish (otoliths, teeth)}

\subsubsection{Overview}

Schmiedrued-Pfyffrüti 618 yielded no fish remains. In contrast, SP 640 revealed a moderately diverse fish fauna (otoliths, teeth) consisting of four taxonomic and ecological groups, i.e. (i) Cyprinidae, a primary freshwater group, (ii) Cyprinodontiformes, an euryhaline and typically highly opportunistic group, (iii) Gobiiformes, a primary marine group when one considers the most speciose family Gobiidae, and (iv) Channa elliptica von Salis, 1967, a member of the amphibious snakeheads (Channidae) (Figs. 4-5). The cyprinids can be recognized owing to the typical shape of their pharyngeal teeth (Fig. 6a-b) and based on utricular otoliths (lapilli), while the identification of the remaining groups is based on saccular otoliths (sagittae, termed otolith in the following, if not mentioned otherwise). Schmiedrued-Pfyffrüti 642 harbours a fish fauna of very low diversity made up of Channa sp. and the same cyprinid taxa as those found in SP 640 (Table 1). The small sizes of utricular and saccular otoliths and teeth (usually $<2 \mathrm{~mm}$ ) indicate that, with the exception of the predatory snakehead, all fish species were small, ranging from 5 to $15 \mathrm{~cm}$ in total length.

\subsubsection{The fish fauna of Schmiedrued-Pfyffrüti 640}

The otoliths of the Cyprinodontiformes are similar to those of Aphanolebias konradi (Reichenbacher, 1988), but display considerable variation in overall shape (high-triangular to low-triangular, Fig. 4a-b) and rostrum length (equal to antirostrum or longer than antirostrum, Fig. 4a-g) (otoliths of $A$. konradi from other sites are illustrated in Jost et al., 2006; Reichenbacher, 1993). Taking the variation of the aforementioned otolith characters into account, the otoliths presented here are interpreted as representing a species flock, i.e. a monophyletic group of species closely related to $A$. konradi (definition of species flock follows Greenwood, 1984). Furthermore, about $10 \%$ of the otoliths exhibit pronounced mineralization of the posteroventral segment of the outer face, recognizable as a hump-like structure (Fig. 4e2, f2). Such mineralization has not been observed in any otoliths of $A$. konradi from other sites, but appears also in some $5 \%$ of the gobiiform otoliths, which are thicker than their normally mineralized counterparts (Fig. 5f2) (see Discussion for possible implications).

Otoliths assigned to the genus Gobius have been described from several other Miocene sites in the Swiss and South German Molasse Basin (Jost et al., 2006; Reichenbacher, 1993; Salis, 1967). Note that we use here the name Gobius in a wider sense (sensu lato) due to the difficulties involved in the identification of fossil gobiiforms at the genus or even at the family level (see Gierl et al., 2013). In addition, the species previously determined as Gobius brevis (Agassiz, 1839) is currently in revision and actually represents a new genus (Gierl and Reichenbacher, in press); we refer to it as "Gobius" brevis in this study. Note also that Gobius latiformis Reichenbacher \& Weidmann, 1992 is a junior synonym of "G." brevis (see Reichenbacher et al., 2007).

The otoliths of "G." brevis are characterized by a quadratic or rectangular shape and possess a well-developed rounded or tapering posterodorsal projection; the anteroventral projection, when present, is short (Fig. 4h-j). Otoliths assigned here to "G." aff. brevis differ from the nominal species in displaying a wide but short posterodorsal projection (Fig. 4k-m). The other three species of gobiiform fishes, i.e. Gobius gregori Reichenbacher, 1993, Gobius helvetiae von Salis, 1967 and Gobius longus von Salis, 1967 (Fig. 4n-w) do not differ from their counterparts found at other, usually slightly older sites in the Molasse Basin (Jost et al., 2006; Reichenbacher et al., 2004).

Moreover, several morphotypes can be distinguished among the gobiiform otoliths. Seven morphotypes are depicted here (Fig. $5 \mathrm{a}-\mathrm{g}$ ), but it would be possible to differentiate several more. Their nomenclature is left open until data on degrees of intra- and interspecific variation in extant species becomes available. The otolith of morphotype 1 (Fig. 5a) is similar to "G." aff. brevis, but differs from it in having a less straight anterior margin and a distinct constriction in the middle of the sulcus. Morphotype 2 (Fig. 5b) resembles $G$. helvetiae, but its dorsal margin displays a prominent projection in the middle and its posteroventral angle is rounded (vs. angular in G. helvetiae). Morphotype 3 (Fig. 5c) cannot be assigned to any of the known species due to its steeply ascending predorsal margin. Morphotype 4 (Fig. 5d) is similar to "G." brevis, but differs in having a narrower sulcus than that seen in "G." brevis. Morphotype 5 (Fig. 5e) appears intermediate between morphotypes 3 and 4, but displays a different curvature of the dorsal margin. Morphotype 6 (Fig. 5f) cannot be assigned to any of the known species due to its quadratic shape and crenulated dorsal margin. Morphotype 7 (Fig. 5g) is similar to "G." brevis and also to morphotype 4, but differs from "G." brevis because the sulcus is narrower, and differs from both in possessing a strong preventral process and a wavy curvature of the anterior margin. 


\subsection{Amphibians and reptiles (teeth, bones)}

The herpetofaunal assemblages in the three levels studied consist largely of teeth and jaw remains of taxa that were widely distributed in Central Europe during the Middle Miocene (Fig. 6). The species diversity is comparatively low (Table 1 ). Remains of an aquatic salamander (Proteidae indet., SP 618, SP 640) are the sole records of amphibians. Eight taxa of reptiles are present, including a crocodile (Crocodylia indet., SP 640, 642), snakes (SP 642), and two subterranean (Anguis sp., Amphisbaenidae indet., SP 618) and four heliophilic lizard taxa (Gekkonidae indet., SP 642; Ophisaurus sp., SP 618; Bavaricordylus sp., SP 642; Lacertidae indet., SP 618, SP 642) (ecological definitions follow Böhme et al., 2006).

\subsection{Turtle eggshells}

Eggshell fragments occur in all studied levels. Two specimens from SP 640 were investigated in detail and can be assigned to the Oofamily Testudoolithidae Hirsch, 1996 (Fig. 7a-d). The eggshell is $400 \mu$ m thick with tightly packed shell units that exhibit a height-to-width ratio of 1.9:1-2.35:1. The shell units are made up of tightly interlocking acicular crystals that radiate from the nucleation site (Fig. 7c), which is consistent with rigid eggshell from fossil and extant turtles (Hirsch, 1983, 1996; Schleich and Kästle, 1988). Accretion lines and straight pores are identified in radial thin sections; pores have a diameter of $31 \mu \mathrm{m}$ (Fig. 7d). Tangential thin sections show approximately 20 pores per square millimetre.

The eggshell microstructure can be distinguished from the Oofamily Testudoflexoolithidae based on their tightly packed shell units and a shell unit height-to-width ratio that is greater than 1:1. Among oospecies assigned to the Testudoolithidae, these specimens differ from the two single records known from the European Miocene (S-Germany) in the greater thickness of their shells (400 $\mu \mathrm{m} v \mathrm{~s}$. $300 \mu \mathrm{m}$ ) (see Schleich and Kästle, 1988, plates 44-45) and are most similar to Late Cretaceous specimens, Emydoolithus laiyangensis Wang et al., 2013 from China and Testudoolithus oosp. from Madagascar (Lawver et al., 2015) in their eggshell thickness and shell unit height-to-width ratio; although these specimens show much fewer pores.

Comparisons with extant turtle eggshell indicate that the studied specimens are similar to those taxa which produce rigid-shelled eggs, such as kinosternids, trionychids, dermatemydids, geoemydids and testudinids (Schleich and Kästle, 1988). Although most of these taxa are characterized by eggshell that is thinner than the specimens studied here, Dermatemys mawii and some testudinids are most similar to them. However, because of the fragmentary nature of the studied specimens, and because associated embryonic or adult bones have not been found (see also Lawver and Jackson, 2014), it is not possible to determine to which of these groups the specimens from SP 640 belong. Therefore, we refer the specimens to Testudoolithidae indet.

\subsection{Small mammals}

All three levels revealed low species diversity and similar sets of species (Table 1). Schmiedrued-Pfyffrüti 618 has yielded the highest number of small-mammal teeth $(\mathrm{n}=163)$, while 49 and 37 specimens were recovered from SP 640 and SP 642, respectively. The most abundant taxon is the cricetid Megacricetodon bavaricus Fahlbusch, 1964 (Fig. 8a), which makes up (approximately) 53\% of the mammalian teeth in SP 618, 61\% in SP 640, and 46\% in SP 642. A second species of cricetid, Democricetodon gracilis Fahlbusch, 1964, occurs in SP 642 (Fig. 8b). The glirid Miodyromys aff. aegercii Baudelot, 1972 (Fig. 8c) and the lagomorph Prolagus oeningensis (König, 1825) are abundant in SP 618, and are also present in SP 640 and 642. Corroded teeth, most likely caused by digestion following predation (see Andrews, 1990), appear in SP 618 ( 10\%), SP $640(\sim 14 \%)$ and SP 642 ( 3\%).

\section{Discussion}

\subsection{Taphonomy}

The presence of aragonitic fossils such as otoliths, turtle eggshell and gastropod shells, and the absence of sorting according to size, suggest that long-distance transport or reworking from much older strata is unlikely. On the other hand, co-occurrences of euryhaline and freshwater species and assemblages of terrestrial and aquatic taxa (see Table 1) point to mixtures of different communities in a dynamic environment, characterized by repeated oscillations between terrestrial, freshwater and slightly saline conditions. The fossil assemblages found in the three studied levels (SP 618, SP 640, SP 642) are therefore interpreted as autochthonous to parautochthonous. Moreover, among the remains of the small mammals, corroded teeth occur in SP 618 and SP 640 and proportions of corroded teeth (10\% in SP $618,14 \%$ in SP 640 ) correlate with the dominance of $M$. bavaricus within the respective smallmammal assemblages. This indicates that the mammalian material is partly derived from raptor pellets. Raptor pellets represent smallmammal assemblages adequately, but may not faithfully reflect the relative frequencies of species (Andrews, 1990). Raptor pellets apparently made only a minor contribution to SP 642, as only a single tooth in the sample of the small-mammal remains from that level is corroded.

\subsection{Palaeoenvironmental implications of SP 618 (late Early Miocene, c. $16.1 \mathrm{Ma}$ )}

Charophytes and freshwater gastropods are very rare and fish remains are completely absent. In contrast, remains of terrestrial vertebrates are abundant and generally well preserved. Thus, the fossil biota clearly indicates that SP 618 represents a terrestrial deposit, most likely a palaeo-soil. Fossorial/subterranean reptiles (Anguis sp., Amphisbaenidae indet.), together with the salamander, suggest that the soil was well oxygenated and well drained, which implies the nearby presence of a river and a humid climate. On the other hand, heliophilic taxa (Ophisaurus sp., Lacertidae indet.) point to open and drier habitats nearby. Their co-occurrence with fossorial/subterranean taxa can perhaps be explained by invoking deposition in raptor pellets, as discussed above for the mammalian tooth sample. The composition of the small-mammal fauna is comparable to those known from lake deposits such as Le Locle Sous le Stand C-13 (MN 7, Kälin et al., 2001) or Mauensee (MN 4b, Reichenbacher et al., 2005).

\subsection{Palaeoenvironmental implications of SP 640 (early Middle Miocene, c. $15.7-15.8 \mathrm{Ma}$ )}

A rich and well-preserved fish fauna (otoliths, teeth) characterizes the biota of this level. Charophytes and shells of freshwater gastropods are also abundant, but gastropod shells are usually fragmented. The presence of a crocodile confirms the aquatic environment indicated by the aforementioned taxa. Shells of land snails, fragments of eggshells of a turtle, and teeth of small-bodied mammals are the main representatives of the terrestrial biota. The co-occurrence of aquatic and terrestrial taxa suggests a freshwater pond or lake and shoreline vicinity. Warm water temperatures can be inferred from the presence of C. elliptica and the crocodile. Extant species of Channa Scopoli, 1777 inhabit warm freshwater ecosystems in Southeast Asia (see Böhme, 2004), and extant crocodiles require a mean annual temperature (MAT) of $\geq 14.2^{\circ} \mathrm{C}$ (Markwick, 1998).

The microstructure of the turtle eggshells (moderate thickness, numerous pores) suggests that they were produced by a species that was not especially adapted for arid environments. Numerous studies have documented the direct correlation between water vapour conductance and porosity with incubation environment for extant eggshells and have demonstrated its application towards the fossil record (Varricchio et al., 2013 and references therein). However, turtle 

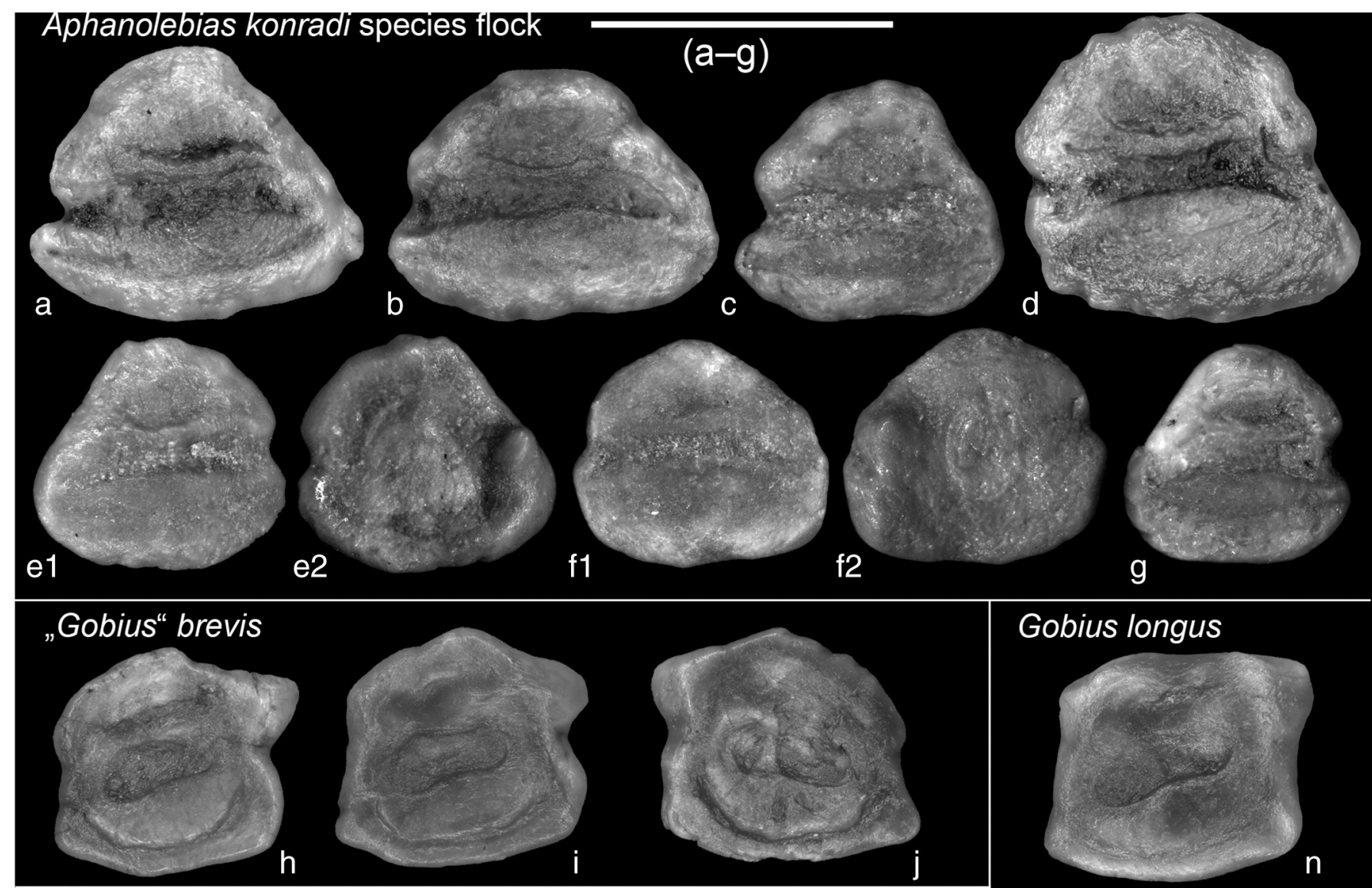

Gobius longus
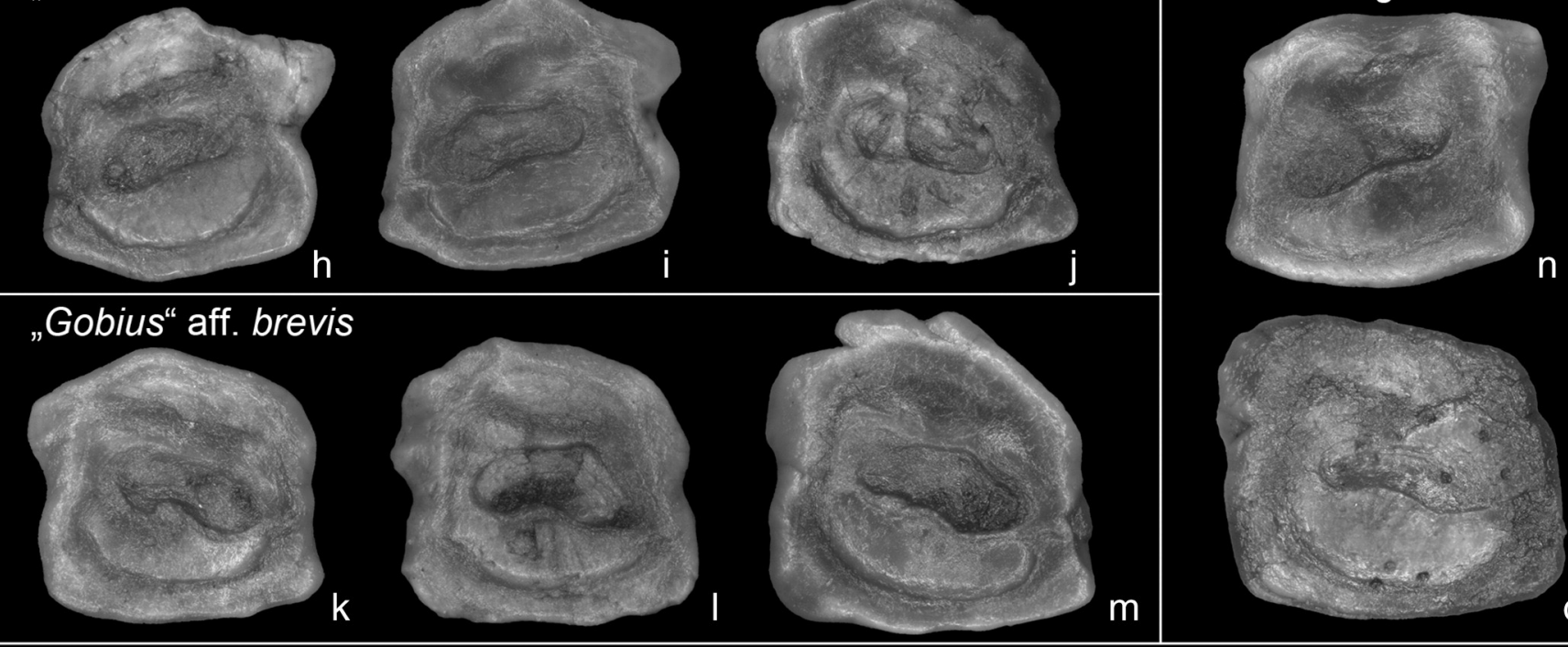

\section{Gobius gregori}
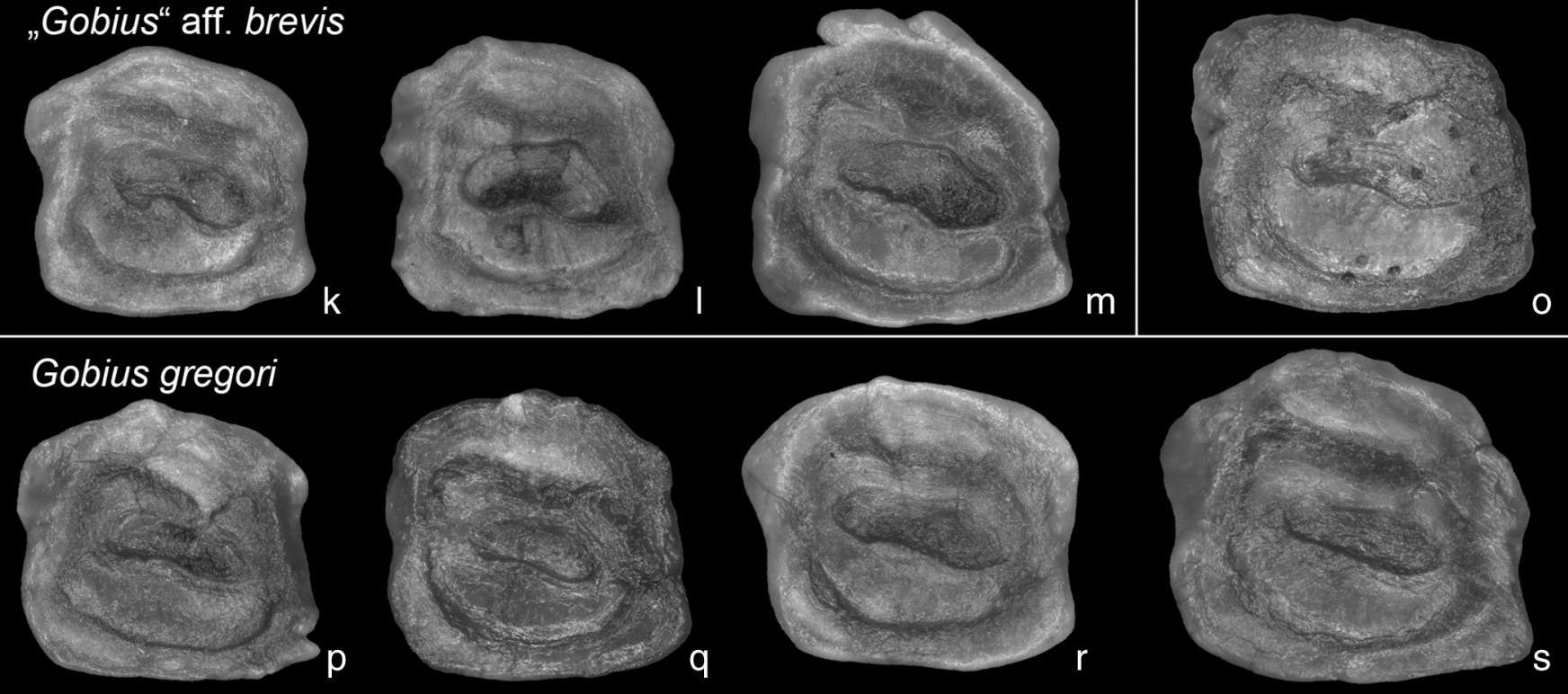

\section{Gobius helvetiae}
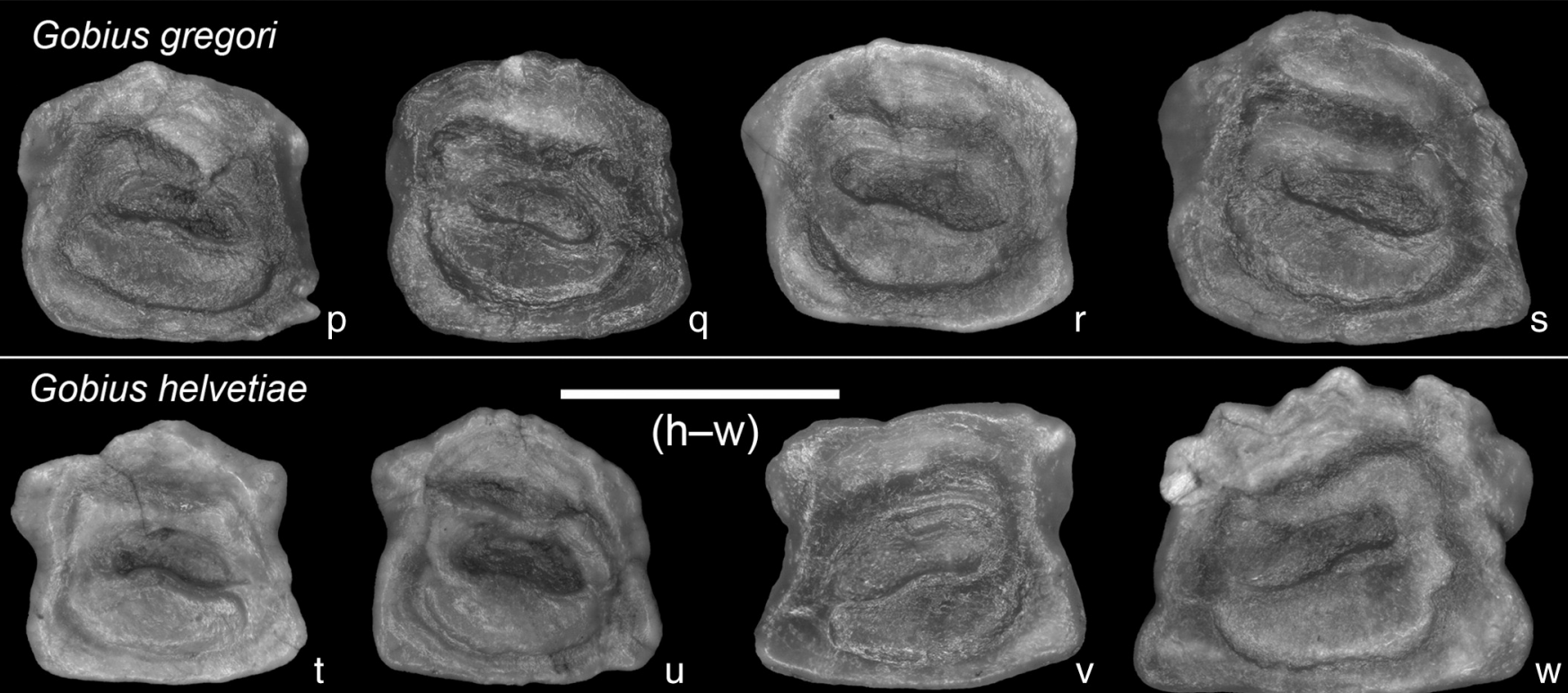


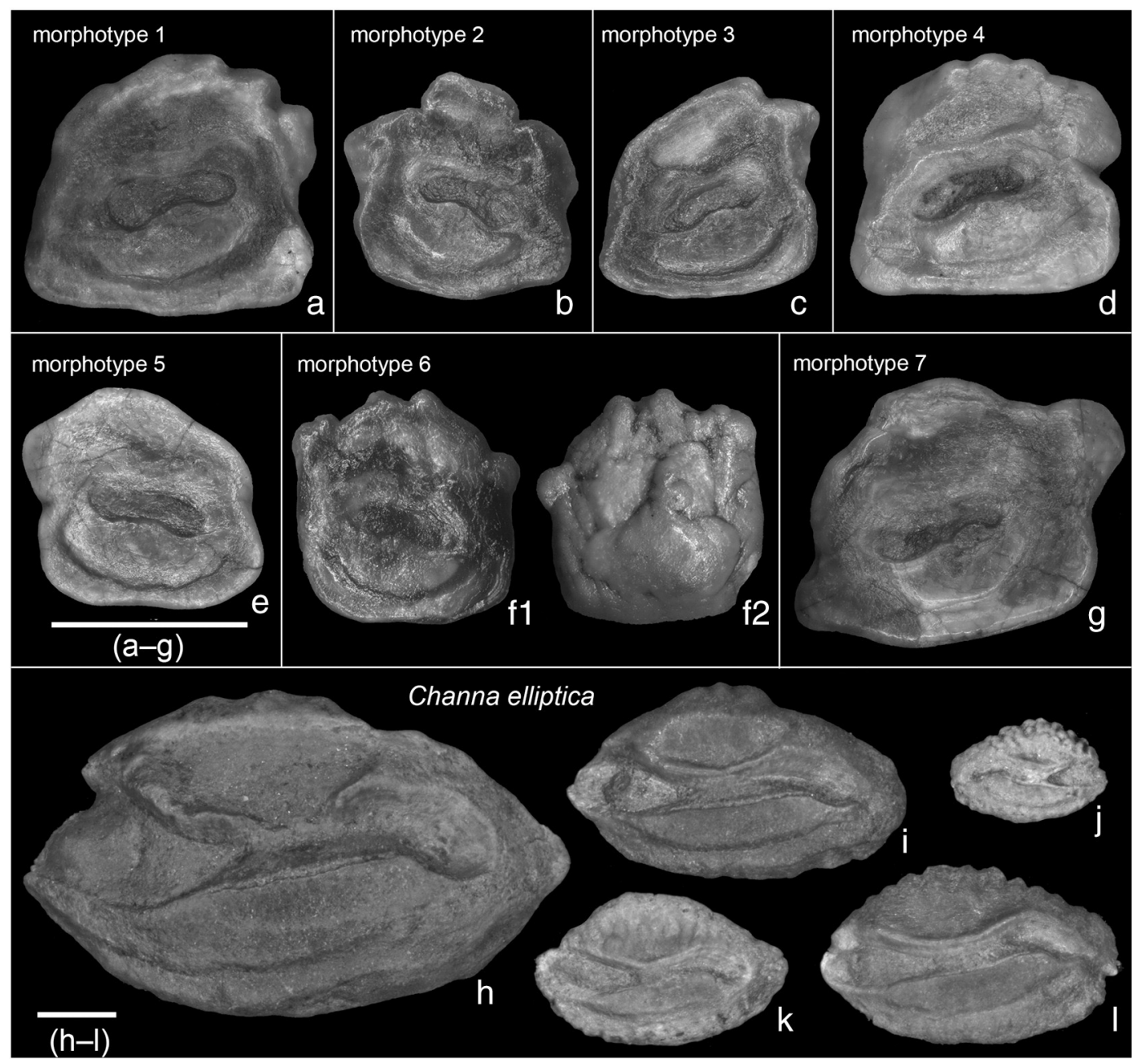

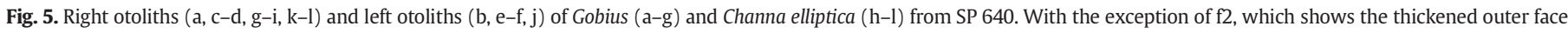
indicating strong mineralization, images show inner otolith faces. Scale bars = 1 mm. SNSB-BSPG 2015 IV/2.

eggshells are very scarce in the fossil record (Lawver and Jackson, 2014; Schleich and Kästle, 1988) and an oospecies ideally adapted to arid environments (with thick eggshells and relatively few pores) has not yet been reported from Paleogene or Neogene deposits. Thus, we have compared our Molasse turtle eggshell to Cretaceous specimens, which is appropriate because of the conservative nature of turtle eggshell composition and microstructure (Hirsch, 1983). Testudoolithus jiangi Jackson et al., 2008, which was discovered as an in situ clutch of eggs in alluvial deposits of the Cretaceous Tiantai Basin (Zhenjiang Province, China), is an example for an oospecies ideally adapted to arid environments; its eggshell has a thickness of $0.7-1.0 \mathrm{~mm}$ ( $v \mathrm{~s}$. $0.4 \mathrm{~mm}$ for the eggshells presented here) and relatively few pores (Jackson et al., 2008). Additionally, E. laiyangensis from the Late Cretaceous of China (Wang et al., 2013) and Testudoolithus oosp. from the Campanian of Madagascar (Lawver et al., 2015) have an eggshell thickness similar to that of the specimens studied here, but no pores were observed in either of these ootaxa, which suggests that these eggs were likely adapted to arid incubation environments and reduced water loss.

The fish fauna, however, is not suggestive of a typical freshwater habitat, because a single freshwater group (Cyprinidae, with two species) together with euryhaline forms such as Aphanolebias spp. and Gobius spp. are dominant (Table 1). Extant species of the killifish genus Aphanius Nardo, 1827 that may represent the nearest living relatives of the extinct genus Aphanolebias Reichenbacher and Gaudant, 2003 thrive in ponds or slowly flowing streams along the Mediterranean and Persian Gulf coasts and in the highlands of Anatolia and Iran; they prefer habitats with unstable salinity and/or water temperature, where most other fishes cannot survive (e.g. Gholami et al., 2015; Teimori et al., 2012; Wildekamp, 1993). Extant species of the Gobiidae, the most speciose family of the Gobiiformes, are usually distributed in shallow marine waters, but many species have adapted to brackish or freshwater habitats (e.g. Kottelat and Freyhof, 2007; Whitehead et al., 1986). Three of the fossil gobiiform species presented here ("G." brevis, G. gregori, G. helvetiae) were probably brackish to euryhaline, since they are known from both brackish and lacustrine sediments, but the fourth species, G. longus, is usually found in freshwater sediments and most likely was a freshwater species (e.g. Jost et al., 2006; Reichenbacher, 1993; Salis, 1967). Nevertheless, despite the abundance of euryhaline and primary marine fish, it is obvious that the area in which SP 640 was deposited was far from the sea, because Central Switzerland was continental during the early Middle Miocene (Berger et al., 2005: fig. 14). The putative species flock of $A$. konradi and the co-existence of at least four species of gobiiform fishes point to a large heterogeneous pond or lake, but the absence of a more

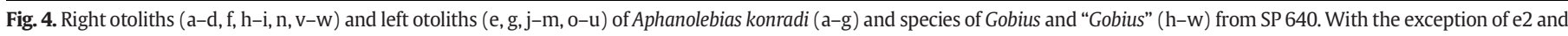
f2, which show outer faces with posteroventral hump-like mineralizations, all images show inner otolith faces. Scale bars = 1 mm. SNSB-BSPG 2015 IV/1. 

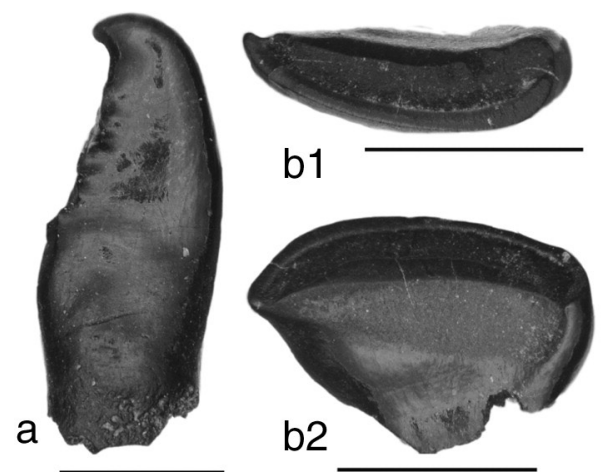

b1
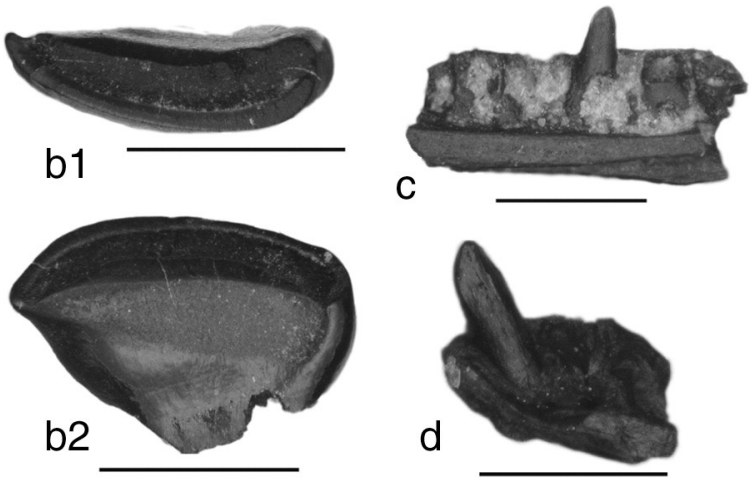

$\mathrm{e}$
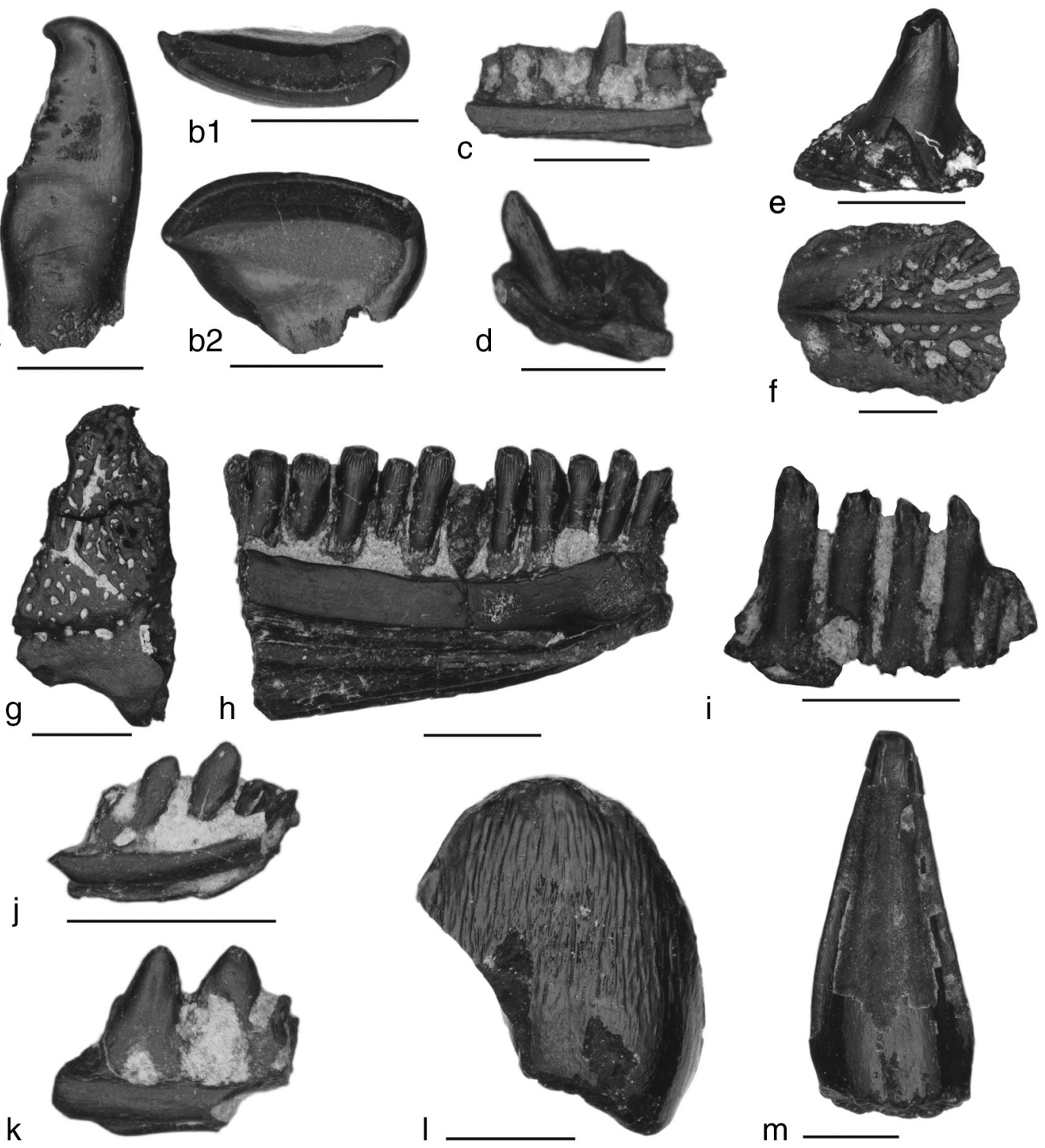

$\mathrm{k}$

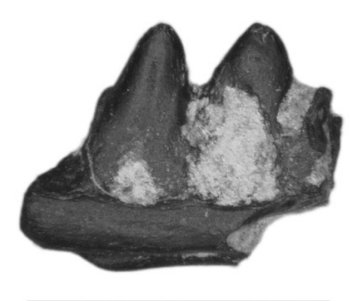

I

$\mathrm{m}$

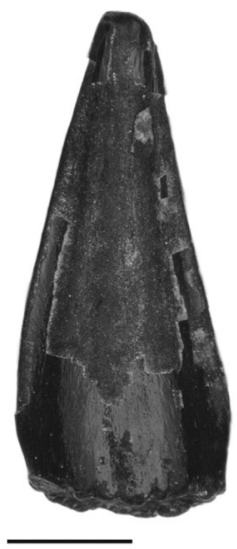

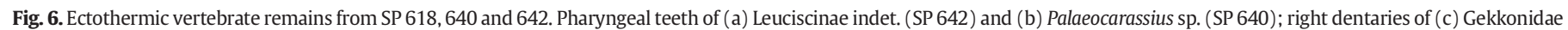

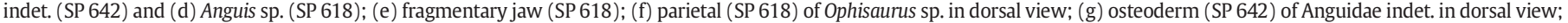

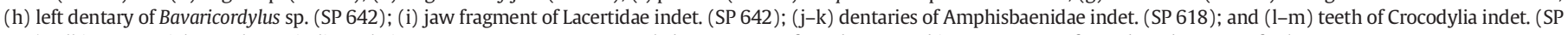
640). All jaw materials are shown in lingual view. SNSB-BSPG $2015 \mathrm{IV} / 3$. Scale bars $=1 \mathrm{~mm}$ for a, b, e-g, and i-m; $=0.5 \mathrm{~mm}$ for c-d; and $=2 \mathrm{~mm}$ for $\mathrm{h}$.

diversified freshwater fish fauna suggest that conditions may have become unfavourable for freshwater fishes from time to time.

Such a faunal composition, marked by the dominance of Cyprinidae, killifishes and gobiiform fishes, with other taxa being rare or absent, has not been reported previously from Molasse sediments. Indeed, a roughly comparable fish assemblage is only known from the evaporitic and post-evaporitic Upper Miocene (Messinian) sediments of the Mediterranean area (Gaudant, 2002). These sediments represent a period of severe evaporation and accumulation of evaporites due to a salinity crisis lasting from $\sim 5.96$ to $\sim 5.33 \mathrm{Ma}$, which resulted from tectonic activity and global climate change (Garcia-Castellanos and Villaseñor, 2011; Hsü et al., 1977; Jiménez-Moreno et al., 2013; Krijgsman et al., 1999). The Messinian salinity crisis promoted the formation of brackish and hypersaline water bodies that gave rise to euryhaline fish assemblages of low diversity, in which Aphanius crassicaudus (Agassiz, 1839) was the dominant species and co-occurred with Gobius ignotus Gaudant, 1979, while other (marine) fish species were rare (Gaudant, 2002). Based on the similarities in the dominance of a killifish together with gobiiform fishes, it can be assumed that the habitats of the fish faunas of the evaporitic and post-evaporitic Messinian sediments and those from SP 640 had particular environmental features in common, of which the most significant were probably high rates of evaporation and associated effects on salinity and water level. Evaporation of the water body documented in SP 640 would have resulted in higher ion concentrations (e.g. $\left.\mathrm{Ca}^{2+}, \mathrm{Mg}^{2+}, \mathrm{Na}^{+}\right)$and increased salinity, and may eventually have led to conditions unfavourable for most freshwater fish and other freshwater organisms. Actualistic examples are the freshwater pools and streams in the semiarid regions of the Zagros Mountains (SW Iran), which, depending on annual precipitation, display highly variable concentration of ions and salinity, and harbour monospecific or very low-diversity fish assemblages dominated by species of Aphanius (Gholami et al., 2015; Teimori et al., 2014; unpublished data of BR). Moreover, the high mineralization seen in c. $10 \%$ of the otoliths of Aphanolebias and c. 5\% of the gobiiform otoliths further supports the assumption of increased ion concentrations in the water body recorded in SP 640. Similarly thickened otoliths of a species of the primary marine Atherinidae have been reported from marls associated with desiccation cracks from the Lower Miocene (Aquitanian) of 

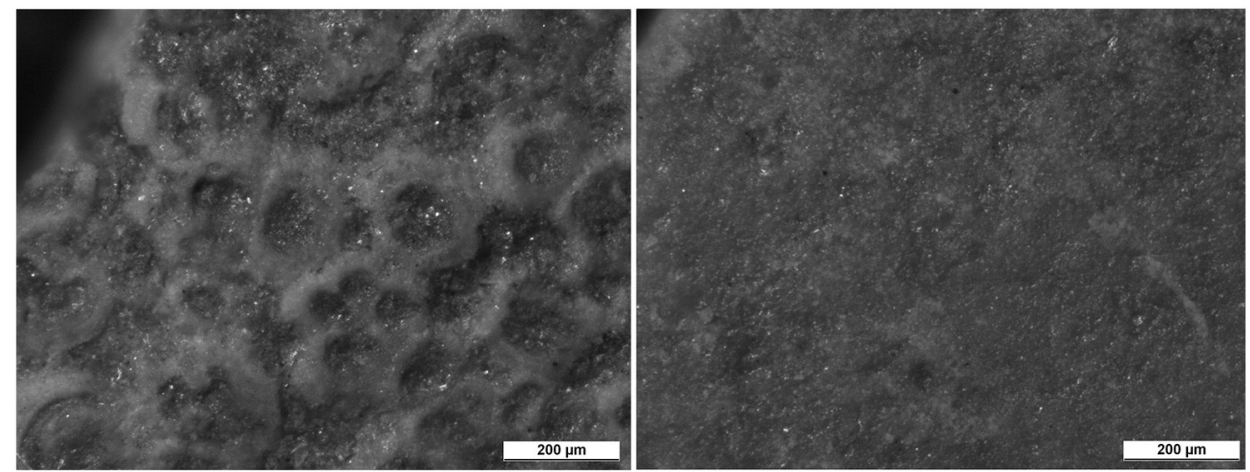

a

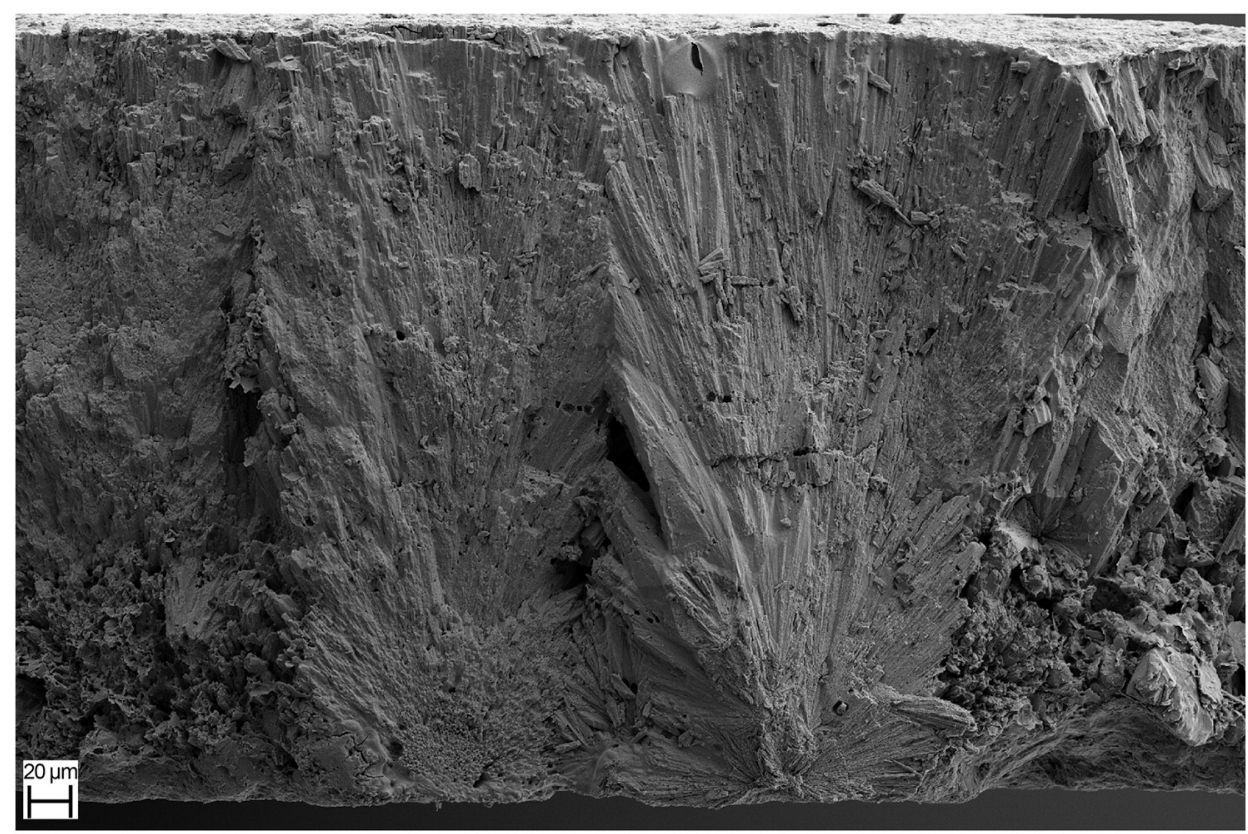

C

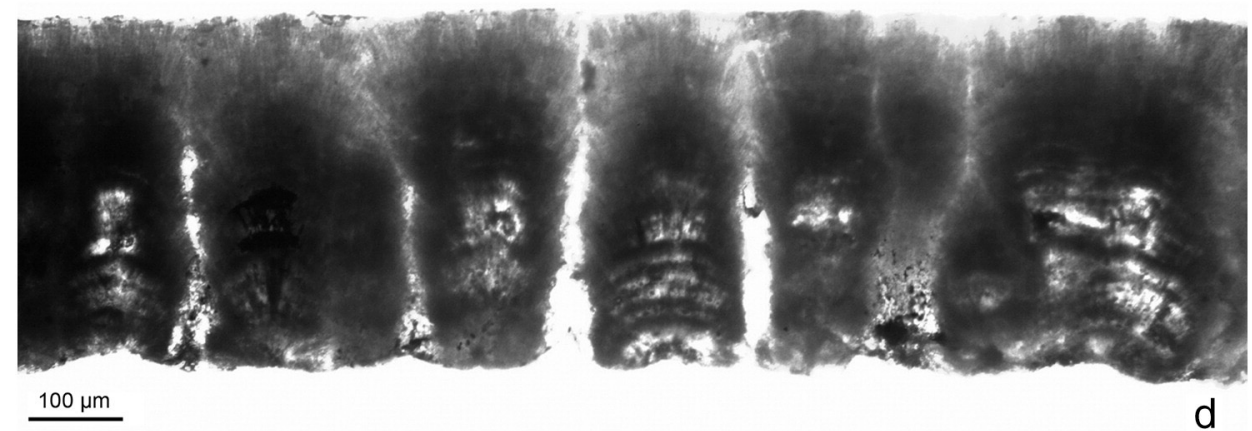

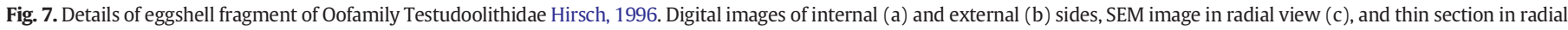
view (d). SNSB-BSPG 2015 IV/4.

the Mainz Basin (Keller et al., 2002; Reichenbacher, 2000). This implies that evaporitic conditions associated with increased $\mathrm{Ca}^{2+}$ concentrations can cause enhanced mineralization of otoliths.

Likewise, increased concentration of $\mathrm{Ca}^{2+}$ in a water body can lead to thickening of the bones of a fish (Chang et al., 2008). Several of the skeletons of both A. crassicaudus and Gobius spp. from the Late Messinian display an overall thickening of their bones, which apparently did not negatively affect the life of the fish (Gaudant, 2002; Meunier and Gaudant, 1987). Thickening of the skeleton has also been described for a fossil cyprinid fish (Hsianwenia wui Chang et al., 2008) from the Pliocene of the Northern Tibetan Plateau, and was interpreted as resulting from high concentrations of $\mathrm{Ca}^{2+}$ in the inland water bodies due to aridification (Chang et al., 2008). Furthermore, a clear link between strongly calcified shells of fossil gastropods and enrichment of $\mathrm{Ca}^{2+}$ due to evaporation has been found by Neubauer et al. (2013).

In summary, the depositional environment of SP 640 can be interpreted as a highly dynamic environment. As a consequence of seasonal aridity and evaporation the salinity changed repeatedly from freshwater to slightly saline, which resulted in biostratinomic mixing of euryhaline fishes and freshwater organisms. Such effects of evaporation in the early Middle Miocene of the North Alpine Foreland Basin are not unexpected, because seasonal aridity has previously been reported 


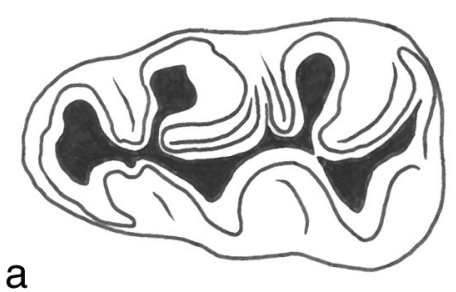

a
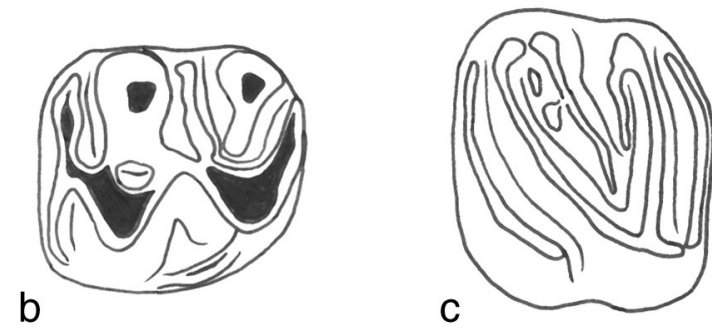

\begin{abstract}
$1 \mathrm{~mm}$
for this time span and this area based on ectothermic vertebrates (Böhme, 2003, 2010; Böhme et al., 2011; Böttcher et al., 2009), plant associations (Rasser et al., 2013) and high variation of oxygen isotopes derived from both fish otoliths (Reichenbacher et al., 2004) and other fossil remains (Tütken et al., 2006). Most of these studies dealt with fossil assemblages that were younger than SP 640; thus SP 640 and probably the Randecker Maar fossil Lagerstätte (Rasser et al., 2013) may record the very first onset of seasonality in the Middle Miocene of the Molasse Basin.
\end{abstract}

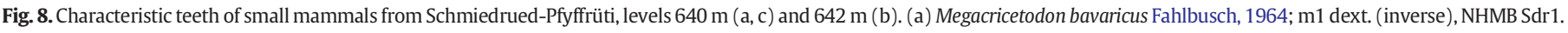
(b) Democricetodon gracilis Fahlbusch, 1964; M2 sin., NHMB Sdr 2. (c) Miodyromys aff. aegercii Baudelot, 1972; M1/2 sin., NHMB Sdr 3.

\subsection{Palaeoenvironmental implications of SP 642 (early Middle Miocene, c. $15.7-15.8 \mathrm{Ma}$ )}

Charophytes, freshwater gastropods, remains of Unionidae, pharyngeal teeth of cyprinids and terrestrial vertebrate remains are abundant and moderately to well preserved, but otoliths are almost absent (Table 1). This fossil assemblage indicates a mixed environment in the vicinity of a river (because of the Unionidae) with an open hinterland (suggested by the heliophilic taxa). An equally warm or slightly warmer climate relative to SP 640 can be assumed because Channa, a crocodile and the girdled lizard Bavaricordylus are present. The girdled lizard family Cordylidae, now restricted to Africa, requires a MAT of $\geq 17{ }^{\circ} \mathrm{C}$ (Haller-Probst, 1997); according to the actualistic approach we conclude that it is the most thermophilous element found at any of the levels studied here.

\subsection{Palaeoclimate in the North Alpine Foreland Basin from the late Early Miocene to the early Middle Miocene}

The onset of seasonal aridity in the early Middle Miocene, as suggested above, is consistent with previous precipitation estimates based on herpetofaunal assemblages from the Ichenhausen and Untereichen-Altenstadt sections in the South German Molasse Basin (Böhme et al., 2011). The Ichenhausen section has yielded five levels with a fossil herpetofauna in superposition (ICH 1-3, ICH 6-7), while Untereichen-Altenstadt contained one level (UA 540) (Abdul Aziz et al., 2010; Böhme et al., 2011).

According to the stratigraphic framework described in Reichenbacher et al. (2013), levels ICH 1-3 correspond to the lowermost part of the Middle Miocene (c. 15.9-16.0 Ma), ICH 6 and UA 540 are approximate time-equivalents of SP 640-642 (c. 15.7-15.8), and ICH 7 is clearly younger (c. 15.2-15.3). The herpetofaunal assemblage of ICH 1-3 is indicative for a humid climate, with mean annual precipitation (MAP) values varying between 923 and $1387 \mathrm{~mm}$ (Böhme et al., 2011). The wet climate assumed for SP 618 (late Early Miocene) is in good agreement with this assumption. ICH 6 and UA 540, however, yielded herpetofaunas suggestive for an arid climate, with MAP values of $253 \mathrm{~mm}$ (ICH 6) and $153 \mathrm{~mm}$ (UA 540) (Böhme et al., 2011). These precipitation estimates support the arguments presented here for the significance of evaporation for the approximately contemporaneous SP 640. The herpetofaunal assemblage of ICH 7 points to a subsequent sharp increase in humidity, with MAP values of $c .800 \mathrm{~mm}$ (Böhme et al., 2011) by c. 15.2-15.3 Ma.

During the Miocene Climate Optimum, the high-amplitude 400- and 100-kyr cycles of variability in Earth's orbital eccentricity exerted a powerful influence on the evolution of global climate (Holbourn et al., 2007). Eccentricity forcing of climate variability has previously been reported for Middle Miocene lacustrine sediments from Spain (Abels et al., 2010; Krijgsman et al., 1994) and the Dinarides (south-eastern Croatia) (Mandic et al., 2011), and for marine sediments of the Vienna Basin (Central Paratethys) (Hohenegger et al., 2008). As pointed out above, the palaeoclimate of the Molasse Basin of Switzerland and Southwest Germany was humid during the late Early Miocene (SP 618, c. 16,1 Ma) and earliest Middle Miocene (ICH 1-3, c. 15.9-16.0 Ma). The onset of seasonality and low mean annual precipitation most likely ensued in the early Middle Miocene by c. 15.7-15.8 Ma (SP 640, ICH 6, UA 540). As a minimum of the 100-kyr eccentricity cycle has been dated to c. $15.75 \mathrm{Ma}$ (Laskar et al., 2004), it is likely that eccentricityforced global climate change was the main controlling factor in the environmental development of the OSM in the North Alpine Foreland Basin.

\section{Summary and conclusion}

Charophytes, gastropods and bivalves, fishes (teeth, otoliths), amphibians, reptiles and small mammals (teeth, jaw remains), as well as fragments of turtle eggshells have been recovered from three levels in superposition ( $618 \mathrm{~m}, 640 \mathrm{~m}, 642 \mathrm{~m}$ ) within the Upper Freshwater Molasse of the site Pfyffrüti (SP) in the Molasse Basin of Central Switzerland. Co-occurrences of terrestrial, freshwater and euryhaline taxa in all three levels indicate repeated shifts from terrestrial to freshwater to slightly saline conditions as a consequence of fluctuations in precipitation and other climatic variables.

SP 618 represents the oldest time span, c. $16.1 \mathrm{Ma}$, and can be interpreted as a palaeo-soil that formed near a river in a largely humid climate.

SP 640 dates to c. 15.7-15.8 Ma, and was laid down in a freshwater to euryhaline lake environment with warm water temperatures. A putative species flock of the killifish Aphanolebias konradi and at least four species of Gobius and "Gobius" characterize its otolith-based fish fauna. Because other gobiiform genera that are currently difficult to identify may be present in this fauna, the genus name Gobius is used here sensu lato. Such a cohort has not been reported previously from any Molasse sediments, but is comparable to Upper Miocene (Messinian) fish faunas known from evaporitic and post-evaporitic sediments of the Mediterranean area. This indicates that the habitats of the early Middle Miocene in the Molasse Basin and those of the Messinian in the Mediterranean area shared some distinctive environmental features, most probably high rates of evaporation, higher ion concentrations and increased salinity. The enhanced mineralization seen in $5-10 \%$ of the otoliths from SP 640 fits well with this assumption because 
similarly enhanced mineralization has previously been reported for both gastropod shells and fish bones in habitats characterized by evaporitic conditions and increased $\mathrm{Ca}^{2+}$ concentrations.

The uppermost level SP 642 represents a mixed environment in the vicinity of a river (presence of Unio) with an open hinterland (presence of heliophilic, ectothermic taxa). An equally warm or slightly warmer climate compared to SP 640 can be assumed because the girdled lizard Bavaricordylus is present; mean annual temperature may thus have been $\geq 17{ }^{\circ} \mathrm{C}$.

Comparison of precipitation estimates based on herpetofaunal assemblages from other sections in the Molasse Basin allows one to conclude that the palaeoclimate of the Molasse Basin of Switzerland and Southwest Germany was humid during the late Early Miocene (c. 16.1 Ma) and earliest Middle Miocene (15.9-16.0 Ma). Low mean annual precipitation most likely ensued in the early Middle Miocene by c. 15.7-15.8 Ma, with SP 640 and probably also the Randecker Maar fossil Lagerstätte representing the earliest onset of seasonality during that time span. Eccentricity-forced global climate change may have been the main controlling factor in the environmental development of the OSM in the Molasse or North Alpine Foreland Basin because a minimum of the 100-kyr eccentricity cycle has previously been reported at c. $15.75 \mathrm{Ma}$

\section{Acknowledgements}

We acknowledge with gratitude and respect the contributions of Ralf Kohring (FU Berlin), who passed away much too early in 2012, and who provided the figures of the eggshell fragments for this paper. We thank Beat Lüdi (Strengelbach, Switzerland) for logistic support in the field. We thank Agnes Fatz (University Tübingen) for producing the photographs for Fig. 6 . We benefited from scientific discussions with Oleg Mandic (Natural History Museum, Vienna) and several other colleagues from the Molasse Group and we are grateful for the constructive comments of the reviewers Werner Schwarzhans (Hamburg, Copenhagen) and Michael Rasser (State Museum for Natural Sciences, Stuttgart).

\section{References}

Abdul Aziz, H., Böhme, M., Rocholl, A., Zwing, A., Prieto, J., Wijbrans, J.R., Heissig, K., Bachtadse, V., 2008. Integrated stratigraphy and ${ }^{40} \mathrm{Ar} /{ }^{39} \mathrm{Ar}$ chronology of the Early to Middle Miocene Upper Freshwater Molasse in eastern Bavaria (Germany). Int J. Earth Sci. 97, 115-134.

Abdul Aziz, H., Böhme, M., Rocholl, A., Prieto, J., Wijbrans, J.R., Bachtadse, V., Ulbig, A., 2010. Integrated stratigraphy and ${ }^{40} \mathrm{Ar} /{ }^{39} \mathrm{Ar}$ chronology of the Early to Middle Miocene Upper Freshwater Molasse in western Bavaria (Germany). Int. J. Earth Sci. 99, 1859-1886.

Abels, H.A., Abdul Aziz, H., Krijgsman, W., Smeets, S.J.B., Hilgen, F.J., 2010. Long-period eccentricity control on sedimentary sequences in the continental Madrid Basin (middle Miocene, Spain). Earth Planet. Sci. Lett. 289, 220-231.

Agassiz, L., 1839. Recherches sur les Poissons fossiles, tome 5. Neuchâtel (Petitpierre).

Andrews, P., 1990. Owls, Caves and Fossils. Predation, Preservation and Accumulation of Small Mammal Bones in Caves With an Analysis of the Pleistocene Cave Fauna From Westerbury-Sub-Mendip, Somerste, UK. The University of Chicago Press, Chicago.

Baudelot, S., 1972. Thèse de l'Univ, Etude des chiroptères, insectivores et rongeurs du Miocène de Sansan (Gers). Paul Sabatier, Toulouse.

Berger, J.-P., Reichenbacher, B., Becker, D., Grimm, M., Grimm, K., Picot, L., Storni, A. Pirkenseer, C., Derer, C., Schaefer, A., 2005. Paleogeography of the Upper Rhine Graben (URG) and the Swiss Molasse Basin (SMB) from Eocene to Pliocene. Int. J. Earth Sci. 94, 697-710.

Böhme, M., 2003. The Miocene climatic optimum: evidence from ectothermic vertebrates of Central Europe. Palaeogeogr. Palaeoclimatol. Palaeoecol. 195, 389-401.

Böhme, M., 2004. Migration history of air-breathing fishes reveals Neogene atmospheric circulation patterns. Geology 32, 393-396.

Böhme, M., 2010. Ectothermic vertebrates (Actinopterygii, Allocaudata, Urodela, Anura, Crocodylia, Squamata) from the Miocene of Sandelzhausen (Germany, Bavaria) and their implications for environment reconstruction and palaeoclimate. Paläontol. Z. $84,3-41$.

Böhme, M., Ilg, A., Ossig, A., Küchenhoff, H., 2006. New method to estimate paleoprecipitation using fossil amphibians and reptiles and the middle and late Miocene precipitation gradients in Europe. Geology 34, 425-428.

Böhme, M., Bruch, A.A., Selmeier, A., 2007. The reconstruction of Early and Middle Miocene climate and vegetation in Southern Germany as determined from the fossil wood flora. Palaeogeogr. Palaeoclimatol. Palaeoecol. 253, 91-114.

Böhme, M., Winklhofer, M., Ilg, A., 2011. Miocene precipitation in Europe: tempora trends and spatial gradients. Palaeogeogr. Palaeoclimatol. Palaeoecol. 304, 212-218.

Böttcher, R., Heizmann, E.P.J., Rasser, M.W., Ziegler, R., 2009. Biostratigraphy and palaeoecology of a Middle Miocene (Karpathian, MN 5) fauna from the northern margin of the North Alpine Foreland Basin (Oggenhausen 2, SW' Germany). N. Jb. Geol. Paläont (Abh.) 254, 237-260.

Chang, M., Wang, X., Liu, H., Miao, D., Zhao, Q., Wu, G., Liu, J., Li, Q., Sun, Z., Wang, N., 2008. Extraordinarily thick-boned fish linked to the aridification of the Qaidam Basin (northern Tibetan Plateau). Proc. Natl. Acad. Sci. U. S. A. 105, 13246-13251.

Doppler, G., Heissig, K., Reichenbacher, B., 2005. Die Gliederung des Tertiärs im süddeutschen Molassebecken. Newsl. Stratigr. 41, 359-375.

Eronen, J.T., Rössner, G.E., 2007. Wetland paradise lost: Miocene community dynamics in large herbivorous mammals from the German Molasse Basin. Evol. Ecol. Res. 9, 471-494.

Etter, W., 1994. Palökologie: Eine methodische Einführung. Birkhäuser Verlag, Basel Boston, Berlin.

Fahlbusch, V., 1964. Die Cricetiden (Mamm.) der Oberen Süsswasser-Molasse Bayerns. Abh. bayer. Akad. Wiss. Math.-nat. Klasse, N.F. 118, 1-136.

Garcia-Castellanos, D., Villaseñor, A., 2011. Messinian salinity crisis regulated by competing tectonics and erosion at the Gibraltar arc. Nature 480, 359-363.

Gaudant, J., 1979. Cherasco (Piemont): un nouveau gisement de poissons fossiles du Messinien continental d'Italie. Géobios 12, 113-121.

Gaudant, J., 2002. La crise messinienne et ses effets sur l'ichthyofaune néogène de la Méditerranée: le témoignage des squelettes en connexion de poissons téléostéens. Geodiversitas 24, 691-710.

Gholami, Z., Esmaeili, H.R., Erpenbeck, D., Reichenbacher, B., 2015. Genetic connectivity and phenotypic plasticity in the cyprinodont Aphanius farsicus from the Maharlu Basin, south-western Iran. J. Fish Biol. http://dx.doi.org/10.1111/jfb.12599.

Gierl, C., Reichenbacher, B., 2015. A new fossil genus of Gobiiformes from the Miocene characterized by a mosaic set of characters. Copeia (in press).

Gierl, C., Reichenbacher, B., Gaudant, J., Erpenbeck, D., Pharisat, A., 2013. An extraordinary gobioid fish fossil from southern France. PLoS ONE 8, e64117.

Gradstein, F.M., Ogg, J.G., Schmitz, M.D., Ogg, G.M., 2012. The Geologic Time Scale Elsevier, Amsterdam.

Graf, H.R., Jost, J., Eberhard, M., Kruysse, H., Kempf, O., 2012. Blatt 1109 Schöftland. Geologischer Atlas Schweiz 1:25000. Erläuterungen 150.

Greenwood, P.H., 1984. What is a species flock? In: Echelle, A.A., Kornfield, I. (Eds.), Evolution of Fish Species Flocks. University of Maine at Orono Press, Orono, Maine, pp. 13-20

Haller-Probst, M., 1997. Die Verbreitung der Reptilia in den Klimazonen der Erde. Cour. Forschungstinst. Senckenb. 203, 1-67.

Heissig, K., 1997. Mammal faunas intermediate between the reference faunas of MN4 and MN6 from the Upper freshwater Molasse of Bavaria. In: Aguilar, J.-P., Legendre, S. Michaux, J. (Eds.), Actes du Congrès BiochroM'97 - Mémoires et Travaux de l'Ecole Pratique des Hautes Etudes. 21. Institut de Montpellier, pp. 537-546.

Hirsch, K.F., 1983. Contemporary and fossil Chelonian eggshells. Copeia 1983, 382-397.

Hirsch, K.F., 1996. Parataxonomic classification of fossil chelonian and gecko eggs J. Vertebr. Paleontol. 16, 752-762.

Hohenegger, J., Andersen, N., Baldi, K., Coric, S., Pervesler, P., Rupp, C., Wagreich, M., 2008 Paleoenvironment of the Early Badenian (Middle Miocene) in the southern Vienna Basin (Austria) - multivariate analysis of the Baden-Sooss section. Geol. Carpath 59, 461-488.

Holbourn, A., Kuhnt, W., Schulz, M., Flores, J.A., Andersen, N., 2007. Orbitally-paced climate evolution during the middle Miocene "Monterey" carbon-isotope excursion. Earth Planet. Sci. Lett. 261, 534-550.

Hsü, K.J., Montadert, L., Bernoulli, D., Cita, M.B., Erickson, A., Garrison, R.E., Kidd, R.B., Mèlierés, F., Müller, C., Wright, R., 1977. History of the Mediterranean salinity crisis. Nature 267, 399-403.

Jackson, F.D., Jin, X.S., Varricchio, D.J., Azuma, Y., Jiang, Y.G., 2008. The first in situ turtle clutch from the Cretaceous Tiantai Basin, Zhejiang Province, China. J. Vertebr Paleontol. 28, 319-325.

Jiménez-Moreno, G., Fauquette, S., Suc, J.-P., 2008. Vegetation, climate and palaeoaltitude reconstructions of the Eastern Alps during the Miocene based on pollen records from Austria, Central Europe. J. Biogeogr. 35, 1638-1649.

Jiménez-Moreno, G., Pérez-Asensio, J.N., Larrasoaña, J.C., Aguirre, J., Civis, J., Rivas-Carballo, M.R., Valle-Hernández, M.F., González-Delgado, J.A., 2013. Vegetation, sea-level, and climate changes during the Messinian salinity crisis. Geol. Soc. Am. Bull. 125, 432-444.

Jost, J., Kälin, D., Schulz-Mirbach, T., Reichenbacher, B., 2006. Late Early Miocene lake deposits near Mauensee, central Switzerland: fish fauna (otoliths, teeth), accompanying biota and palaeoecology. Eclogae Geol. Helv. 99, 309-326.

Kälin, D., Kempf, O., 2009. High-resolution stratigraphy from the continental record of the Middle Miocene Northern Alpine Foreland Basin of Switzerland. N. Jb. Geol. Paläont. (Abh.) 254, 177-235

Kälin, D., Berger, J.-P., Engesser, B., Weidmann, M., 2001. Paléontologie et âge de la Molasse d'eau douce supérieure neuchâtelois. Schweiz. Paläont. Abh. 121, 63-99.

Keller, T., Reichenbacher, B., Gaudant, J., 2002. Erstbeschreibung von AtherinidenSkeletten (Pisces, Teleostei, Atheriniformes) mit Otolithen in situ aus den Unteren Hydrobien-Schichten (Wiesbaden-Formation) des Mainzer Beckens, mit einem Beitrag zur Sedimentologie und Paläoökologie. Cour. Forschungstinst. Senckenb. 237, 319-343.

König, C.D.E., 1825. Centuria prima, Icones fossilium sectiles. G.B. Sowerby, London.

Kottelat, M., Freyhof, J., 2007. Handbook of European Freshwater Fishes. Kottelat \& Freyhof, Cornol, Switzerland, Berlin, Germany. 
Krijgsman, W., Langereis, C.G., Daams, R., Vandermeulen, A.J., 1994. Magnetostratigraphic dating of the Middle Miocene climate-change in the continental deposits of the Aragonian type area in the Calatayud-Teruel Basin (central Spain). Earth Planet. Sci. Lett. 128, 513-526.

Krijgsman, W., Hilgen, F.J., Raffi, I., Sierro, F.J., Wilson, D.S., 1999. Chronology, causes and progression of the Messinian salinity crisis. Nature 400, 652-655.

Kuhlemann, J., Kempf, O., 2002. Post-Eocene evolution of the North Alpine Foreland Basin and its response to Alpine tectonics. Sediment. Geol. 152, 45-78.

Laskar, J., Robutel, P., Joutel, F., Gastineau, M., Correia, A.C.M., Levrard, B., 2004. A longterm numerical solution for the insolation quantities of the Earth. Astron. Astrophys. 428, 261-285.

Lawver, D.R., Jackson, F.D., 2014. A review of the fossil record of turtle reproduction: eggs, embryos, nests and copulating pairs. Bull. Peabody Mus. Nat. Hist. 55, 215-236.

Lawver, D.R., Rasoamiaramanana, A.R., Werneburg, I., 2015. An occurrence of fossil eggs from the Mesozoic of Madagascar and a detailed observation of eggshell microstructure. J. Vertebr. Paleontol. 35 (6)

Lemcke, K., 1988. Geologie von Bayern I: Das bayerische Alpenvorland vor der Eiszeit Erdgeschichte, Bau, Bodenschätze. Schweizerbart, Stuttgart.

Mandic, O., de Leeuw, A., Vuković, B., Krijgsman, W., Harzhauser, M., Kuiper, K.F., 2011. Palaeoenvironmental evolution of Lake Gacko (Southern Bosnia and Herzegovina): impact of the Middle Miocene Climatic Optimum on the Dinaride Lake System. Palaeogeogr. Palaeoclimatol. Palaeoecol. 299, 475-492.

Markwick, P.J., 1998. Fossil crocodilians as indicators of Late Cretaceous and Cenozoic climates: implication for using paleontological data in reconstructing palaeoclimate. Palaeogeogr. Palaeoclimatol. Palaeoecol. 137, 205-271.

Meunier, F.J., Gaudant, J., 1987. Sur un cas de pachyostose chez un poisson du Miocène terminal du bassin méditerranéen, Aphanius crassicaudus (Agassiz), (Teleostei, Cyprinodontidae). C. R. Acad. Sci. II 305, 925-928.

Nardo, J.D., 1827. Prodomus et disquisitionum Adriaticae ichthyologiae. Giornale di Fisica, Chimica, Storia naturale, Medicina ed Arti Pavia 2 (10), 34-40.

Neubauer, T.A., Mandic, O., Harzhauser, M., Hrvatovic, H., 2013. A new miocene lacustrine mollusc fauna of the Dinaride Lake System and its palaeobiogeographic, palaeoecologic and taxonomic implications. Palaeontology 56, 129-156.

Prieto, J., Böhme, M., Maurer, H., Heissig, K., Abdul Aziz, H., 2009. Sedimentology, biostratigraphy and environments of the Untere Fluviatile Serie (Lower and Middle Miocene) in the central part of the North Alpine Foreland Basin - implications for basin evolution. Int. J. Earth Sci. 98, 1767-1791.

Rasser, M.W., Bechly, G., Böttcher, R., Ebner, M., Heizmann, E.P.J., Höltke, O., Joachim, C. Kern, A.K., Kovar-Eder, J., Nebelsick, J.H., Roth-Nebelsick, A., Schoch, R.R. Schweigert, G., Ziegler, R., 2013. The Randeck Maar: palaeoenvironment and habitat differentiation of a Miocene lacustrine system. Palaeogeogr. Palaeoclimatol. Palaeoecol. 392, 426-453.

Reichenbacher, B, 1988. Die Fischfauna der Kirchberger Schichten (Unter-Miozän) an der Typuslokalität Illerkirchberg bei Ulm. Stuttgarter Beitr. Naturkd. B 139, 1-53.

Reichenbacher, B., Weidmann, M., 1992. Fisch-Otolithen aus der oligo-/miozänen Molasse der West-Schweiz und der Haute-Savoie (Frankreich). Stuttgarter Beitr. Naturkd. B $184,1-83$.

Reichenbacher, B., 1993. Mikrofaunen, Paläogeographie und Biostratigraphie der miozänen Brack- und Süßwassermolasse in der westlichen Paratethys unter besonderer Berücksichtigung der Fisch-Otolithen. Senckenb. Lethaea 73, 277-374.

Reichenbacher, B., 1999. Preliminary otolith-zonation in continental Tertiary deposits of the Paratethys and adjacent areas. N. Jb. Geol. Paläont. (Abh.) 214, 375-390.

Reichenbacher, B., 2000. Das brackisch-lakustrine Oligozän und Unter-Miozän im Mainzer Becken und Hanauer Becken: Fischfaunen, Paläoökologie, Biostratigraphie Paläogeographie. Cour. Forschungstinst. Senckenb. 222, 1-143.

Reichenbacher, B., Gaudant, J., 2003. On Prolebias meyeri (Agassiz) (Teleostei, Cyprinodontiformes) from the Oligo-Miocene of the Upper Rhinegraben area, with the establishment of a new genus and a new species. Eclogae Geol. Helv. 99, 509-520.
Reichenbacher, B. Prieto J 2006. Lacustrine fish faunas (Teleostei) from the Karpatian of the northern Alpine Molasse Basin, with a description of two new species of Prolebias Sauvage. Palaeontogr Abt. A 278, 87-95

Reichenbacher, B., Böhme, M., Heissig, K., Prieto, J., Kossler, A., 2004. New approach to assess biostratigraphy, palaeoecology and past climate in the South German Molasse Basin during the Early Miocene (Ottnangian, Karpatian). Cour. Forschungstinst. Senckenb. 249, 71-89.

Reichenbacher, B., Kälin, D., Jost, J., 2005. A fourth St. Gallen Formation cycle (?) in the Karpatian Upper Marine Molasse of central Switzerland. Facies 51, 160-172.

Reichenbacher, B., Gaudant, J., Griessemer, T.W., 2007. A late Burdigalian gobiid fish, Gobius brevis (AGASSIZ, 1839), in the Upper Hydrobia Beds in the middle Upper Rhine Graben (W-Germany). Paläontol. Z. 81, 365-375.

Reichenbacher, B., Krijgsman, W., Lataster, Y., Pippèrr, M., Van Baak, C.G.C., Chang, L., Kälin, D., Jost, J., Doppler, G., Jung, D., Prieto, J., Abdul Aziz, H., Böhme, M., Garnish, J., Kirscher, U., Bachtadse, V., 2013. A new magnetostratigraphic framework for the Lower Miocene (Burdigalian/Ottnangian, Karpatian) in the North Alpine Foreland Basin. Swiss J. Geosci. 106, 309-334.

Sach, V.J., Gaudant, J., Reichenbacher, B., Böhme, M., 2003. Die Fischfaunen der Fundstellen Edelbeuren-Maurerkopf und Wannenwaldtobel 2 (Miozän, Obere Süßwassermolasse, SW-Deutschland). Stuttg. Beitr. Natkd. Ser. B (Geol. Palaeontol.) 334, 1-19.

Salis, K.v., 1967. Geologische und sedimentologische Untersuchungen in Molasse und Quartär südöstlich Wolhusen (Entlebuch, Kt. Luzern). Mitteilungen der Naturforschenden Gesellschaft Luzern XXI pp. 1-106.

Schleich, H.H., Kästle, W., 1988. Reptile Egg Shells, SEM Atlas. Gustav Fischer, Stuttgart, New York.

Scholz, H., 1989. Die Obere Meeresmolasse (OMM) am Südrand des Molassebeckens im Allgäu. Geol. Bavarica 94, 49-81.

Scopoli, C.D.E., 1877. Introductio ad historiam naturalem, sistens genera lapidum, plantarum et animalium hactenus detecta, caracteribus essentialibus donata, in tribus divisa, subinde ad leges naturae. Prague.

Teimori, A., Schulz-Mirbach, T., Esmaeili, H.R., Reichenbacher, B., 2012. Geographical differentiation of Aphanius dispar (Teleostei: Cyprinodontidae) from Southern Iran. J. Zool. Syst. Evol. Res. 50, 289-304.

Teimori, A., Esmaeili, H.R., Erpenbeck, D., Reichenbacher, B., 2014. A new and unique species of the genus Aphanius Nardo, 1827 (Teleostei: Cyprinodontidae) from Southern Iran: a case of regressive evolution. Zool. Anz. 253, 327-337.

Tütken, T., Vennemann, T.W., Janz, H., Heizmann, E.P.J., 2006. Palaeoenvironment and palaeoclimate of the Middle Miocene lake in the Steinheim basin, SW Germany: a reconstruction from $\mathrm{C}, \mathrm{O}$, and $\mathrm{Sr}$ isotopes of fossil remains. Palaeogeogr. Palaeoclimatol. Palaeoecol. 241, 457-491.

Varricchio, D.J., Jackson, F.D., Jackson, R.A., Zelenitsky, D.K., 2013. Porosity and water vapor conductance of two Troodon formosus eggs: an assessment of incubation strategy in a maniraptoran dinosaur. Paleobiology 39, 278-296.

Wang, Q., Wang, X.L., Zhao, Z.K., Zhang, J.L., Jiang, S.X., 2013. New turtle egg fossil from the Upper Cretaceous of the Laiyang Basin, Shandong Province, China. Anais Da Academia Brasileira De Ciencias 85, pp. 103-111.

Whitehead, P.J.P., Bauchot, M.-L., Hureau, J.-C., Nielsen, J., Tortonese, E., 1986. Fishes of the North-eastern Atlantic and the Mediterranean. Unesco, Richard Clay (The Chaucer Press) Ltd, Paris, Bungay.

Wildekamp, R.H., 1993. A World of Killies, Volume 1: Atlas of Oviparous Cyprinodontiform Fishes of the World Genera Adamas, Adinia, Aphanius, Aphyoplatys and Aphyosemion. American Killifish Association, Mishawaka, Indiana. 